\author{
Ana Holjevac Tuković \\ Mate Rupić
}

(Hrvatski memorijalno-dokumentacijski centar Domovinskog rata, Zagreb)

\title{
ARHIVSKI FONDOVI SRPSKE PROVENIJENCIJE POHRANJENI U HRVATSKOME MEMORIJALNO- DOKUMENTACIJSKOM CENTRU DOMOVINSKOG RATA
}

UDK 930.25(497.5=163.41)

Pregledni rad

Primljeno: 12. 2. 2020.

\begin{abstract}
Članak daje pregled arhivskih fondova i zbirki nastalih radom paradržavnih civilnih i vojnih ustanova (i postrojbi) pobunjenih Srba na okupiranom području Republike Hrvatske: skupštine i vlade Republike Srpske Krajine, pripadajućih ministarstava, pravosudnih i upravnih tijela na lokalnoj razini, političkih stranaka i udruga, te zonskih štabova i njihovih sljednika, korpusā Srpske vojske Krajine. Prikazano je i gradivo nastalo radom Jugoslavenske narodne armije, pohranjeno u Centru, koja je u vremenu svoje transformacije prešla i u Vojsku Republike Srpske Krajine, kao i u Vojsku Republike Srpske. Oblikovani arhivski fondovi i zbirke većim dijelom pripadaju cjelini arhivskog gradiva Republike Srpske Krajine (Srpske Autonomne Oblasti Krajine), prikupljenog nakon oslobodilačkih vojno-redarstvenih operacija Bljesak i Oluja.

Ključne riječi: Domovinski rat, arhivski fondovi i zbirke Republike Srpske Krajine, Jugoslavenska narodna armija, Hrvatski memorijalno-dokumentacijski centar Domovinskog rata, struktura upravnih i vojnih arhivskih fondova i zbirki
\end{abstract}

\section{Uvod}

Arhivsko gradivo paradržavnih tijela nastalih radom civilnih i vojnih institucija pobunjenih Srba na okupiranom području Republike Hrvatske (RH) u razdoblju 1990. - 1995., te fragmentarno sačuvano gradivo Jugoslavenske narodne armije, pohranjeno je u Hrvatskom memorijalno-dokumentacijskom 
centru Domovinskog rata (HMDCDR). ${ }^{1}$ Prikupljeno gradivo sređuje se i trajno čuva, a upravo je sređenost gradiva i njegova dostupnost jedan od glavnih preduvjeta za objektivno i znanstveno istraživanje te cjeloviti prikaz Domovinskog rata. Količina konvencionalnog arhivskog gradiva pohranjenog u HMDCDR-u iznosi oko 310 dužnih metara (dalje d/m).

Prema zakonskoj osnovi, navedeno gradivo nastalo u Domovinskom ratu trebalo bi biti predano HMDCDR-u kao središnjoj ustanovi za njegovu pohranu i sređivanje, ali dio gradiva pohranjen je u državnim arhivima. ${ }^{2}$ Ipak, budući da HMDCDR vodi evidenciju tog gradiva, odlučeno je da zbog značaja koje gradivo ima za područja koja su u nadležnosti pojedinih državnih arhiva i u kojima je gradivo pohranjeno, ali i zbog nedostatka smještajnih kapaciteta HMDCDR-a, ono neće biti izmješteno. Prvobitni imatelji gradiva bili su Protuobavještajna agencija (POA) i Vojnoobavještajna agencija (VOA) Ministarstva obrane Republike Hrvatske (MORH), a koji su u razdoblju od svibnja do rujna 2004. Hrvatskome državnom arhivu (HDA) predali 115 ambalažnih kutija (dalje kut.) i 1181 registrator gradiva Republike Srpske Krajine (RSK). Gradivo je u prosincu 2005. godine predano u depozit HMDCDR-u, gdje je dobilo skupni naziv Paradržavne i paravojne postrojbe na okupiranome području RH 1990. - 1995. Gradivo JNA je naknadno nadopunjeno preuzimanjem u dva navrata, akvizicijama iz 2013. i 2014., a radilo se o gradivu 5. vojne oblasti Ratnoga vazduhoplovstva i protuvazdušne odbrane i 32. korpusa JNA.

\section{Primopredaja i sređivanje arhivskoga gradiva}

Arhivsko gradivo Paradržavnih i paravojnih postrojbi na okupiranom području RH 1990.-1995. od iznimne je važnosti za istraživanje povijesti Domovinskog rata i ono je primarni izvor za istraživanje društveno-političkih, administrativno-upravnih, gospodarskih i vojno-sigurnosnih odnosa na okupiranom području Hrvatske. Osim gradiva preuzetog od HDA, gradivo se

\footnotetext{
${ }^{1}$ Službeni naziv srpske paradržave pišemo bez navodnika, a na jednak način tretiraju se i imena institucija u RSK. Dakako, to što u tekstu uz spomen "SAO Krajine" ili "Republike Srpske Krajine" i njezinih paravojnih formacija neće biti navodnih znakova, ne znači da autori okupirano područje Republike Hrvatske na kojem su pobunjeni Srbi uspostavili svoju vlast i proglasili paradržavnu tvorevinu smatraju legitimnim državnim subjektom. U svojim izdanjima te pri imenovanju i formiranju naziva arhivskih fondova Hrvatski memorijalno-dokumentacijski centar Domovinskog rata nazive srpske paradržave i njenih institucija stavlja u navodnike.

${ }^{2}$ Državni arhivi, te druge pravne i fizičke osobe koje raspolažu dokumentacijom nastalom u Domovinskom ratu ili vezanom uz rat, dužne su je predati HMDCDR-u. Način predaje utvrđuje se sporazumno s HMDCDR-om, a na traženje predavatelja, HMDCDR može za njega o svom trošku izraditi kopiju dokumentacije koju preuzima (Zakon o Hrvatskom memorijalnodokumentacijskom centru Domovinskog rata, NN 178/2004).
} 
preuzelo i preuzima i od drugih imatelja. Od većih akvizicija treba spomenuti dokumentaciju preuzetu od Vojne policije Zemunik (oko 40 arhivskih kut.), Državnoga arhiva Karlovac (oko 900 arhivskih kut.) i Središnjega vojnog arhiva u Zagrebu (otprilike $25 \mathrm{~d} / \mathrm{m}$ svežnjeva). A s obzirom na imatelje koji upravo predaju ili će tek predati gradivo, fondovi se RSK neprestano nadopunjuju i sređuju. Sustavno sređivanje otežavaju nestrukturirani primopredajni zapisnici, bez jasno naznačenih cjelina ili detaljnijeg popisa gradiva, pa mogu poslužiti samo kao orijentacijsko pomagalo. Pri sređivanju, otegotnu okolnost predstavlja i izdvajanje gradiva radi izrade Memorijala za tužbu protiv Jugoslavije, a koje je nakon okončanja Tužbe protiv Srbije (2015.) bilo potrebno vratiti na mjesto $u$ arhivske fondove nastale radom određenog stvaratelja. Gradivo time ne predstavlja samo povijesni izvor za istraživače, nego i bazu za svakodnevno traženje načina ostvarivanja određenih prava ili ispunjavanja obveza pravnih i fizičkih osoba, kako za potrebe HMDCDR-a, tako i za potrebe pravosudnih tijela, državnih odvjetništva, policijskih uprava i vojnih sigurnosnih službi RH. ${ }^{3}$

Obrada i sređivanje arhivskog gradiva zahtijeva poznavanje povijesti, strukture i rada stvaratelja i njegovog načina upravljanja spisima, od njihovog zaprimanja u pisarnici, obrade u okviru pojedinih nižih i viših ustrojbenih jedinica i konačnog odlaganja u pismohranu. Metodološki gledano, potrebno je sagledati cjelovitu strukture uprave RSK i identificirati pojedine stvaratelje prema službenim glasilima ili arhivskim izvorima, što otežavaju učestale izmjene i neuredan odnos spram legislative i uredskog poslovanja, kao i nastojanja vlasti RSK da prate i usklađuju svoje zakone s legislativom Savezne Republike Jugoslavije (SRJ). Podrobna razrada povijesti stvaratelja stoga je, $\mathrm{s}$ arhivističkog aspekta, neophodna, te se, u pravilu, najprije utvrđuje njegova hijerarhijska struktura, koja omogućuje najnužniju orijentaciju. Razina i brzina sređivanja ovise i o sačuvanosti izvornih obavijesnih/registraturnih pomagala (kazala i urudžbenih zapisnika), koja svakako olakšavaju upoznavanje poretka i cjeline arhivskog gradiva, povezujući ga s organizacijskim i funkcionalnim kontekstom u kojem nastaje, kao skup informacija koje proizlaze iz ustroja, funkcija i nadležnosti svakog pojedinog stvaratelja. ${ }^{4}$

${ }^{3}$ Ana Holjevac Tuković i Mate Rupić, „Arhivski fondovi paradržavnih ustanova Republike Srpske Krajine pohranjeni u Hrvatskom memorijalno-dokumentacijskom centru Domovinskog rata“, u: Arhivi i Domovinski rat, 49. savjetovanje hrvatskih arhivista, 26. - 28. listopada 2016. Plitvice, ur. Silvija Babić (Zagreb: Hrvatsko arhivističko društvo, 2016), 25-45.

${ }^{4}$ Isto. 


\section{Povijest stvaratelja: protuustavno djelovanje pobunjenih Srba u RH i ustrojavanje paradržavnih tijela vlasti}

Kako bi se shvatila upravna povijest i povijest stvaratelja arhivskih fondova i zbirki Paradržavnih i paravojnih postrojbi na okupiranom području RH 1990.-1995., potrebno je podsjetiti na razvoj višestranačja i demokratizaciju društva, koji su doveli do demokratskih izbora u Socijalističkoj Republici Hrvatskoj (SRH), i to u travnju i svibnju 1990., a na kojima je pobijedila Hrvatska demokratska zajednica (HDZ). Nakon konstituiranja višestranačkog Sabora 30. svibnja 1990., hrvatske vlasti pokušavale su s predstavnicima Srba u Hrvatskoj postići dogovor o rješenju srpskog pitanja, tj. o donošenju zakona kojima bi se osigurao visok stupanj autonomije i zaštite etničkih prava srpskoj manjini u Hrvatskoj. No, hrvatsko-srpski razgovori odvijali su se u izrazito negativnom ozračju, opterećeni huškačkom medijskom kampanjom protiv demokratskih procesa u Hrvatskoj, kao i brojnim incidentima srpskih ekstremista i protuhrvatskim mitinzima održanim na područjima gdje je srpsko stanovništvo bilo u većini. Srbi u Hrvatskoj još su u veljači 1990. godine osnovali Srpsku demokratsku stranku (SDS) i u njezinom se programu tvrdilo kako je regionalna podijeljenost Hrvatske zastarjela i da to ne odgovara historijskim interesima srpske nacije. Stranka je predložila novu administrativnu podjelu, što je kasnije preraslo u zahtjev za potpunom autonomijom i potpunim odvajanjem od Hrvatske. Potrebno je naglasiti i da je veliki broj hrvatskih Srba glasao za hrvatske komuniste, smatrajući da bi pobjeda Saveza komunista Hrvatske - Stranke demokratskih promjena (SKH-SDP) mogla zaustaviti moguće političke promjene u Hrvatskoj. No, to je promijenila uvjerljiva pobjeda HDZ-a, nakon koje, u razdoblju između dva izborna kruga i uspostave višestranačkoga Sabora RH, SDS zaoštrava političku retoriku. Povećava se također i broj incidenata, što kulminira nedolaskom zastupnika SDS-a na prvu svečanu sjednicu Sabora RH. ${ }^{5}$ Tako dolazi do prekida političkog dijaloga vodstva Srba u Hrvatskoj (koji su konstituirali vlast na lokalnoj, općinskoj razini) s institucijama hrvatske vlasti i njihovim demokratski izabranim predstavnicima: Skupština općine Knin 27. lipnja 1990. donosi odluku o osnivanju i konstituiranju Zajednice općina Sjeverne Dalmacije i Like, ${ }^{6}$ a odluke o pristupanju u navedenu Zajednicu donose i Skupština općine Donji Lapac (28. lipnja), Skupština općine Gračac (29. lipnja), Skupština općine Obrovac (12. srpnja), Skupština općine Dvor (17. srpnja), Skupština općine Vojnić (24. srpnja), Skupština općine Glina (24. srpnja), Skupština općine Kostajnica (19. prosinca), dok Skupština općine Benkovac 6. kolovoza pristupa Zajednici općina Knin.

${ }^{5}$ Domagoj Knežević, „Srpska demokratska stranka od osnivanja do konstituiranja prvoga višestranačkog Sabora“, Časopis za suvremenu povijest 43 (2011), 1: 7-24.

${ }^{6}$ Službeni vjesnik općine Drniš, Knin i Šibenik, 12/1990. 
Na rezultate izbora u Hrvatskoj, vojne vlasti Socijalističke Federativne Republike Jugoslavije (SFRJ) reagirale su razoružanjem Hrvatske. Ono je planirano i ubrzano provedeno prije nego što je u Hrvatskoj, sukladno rezultatima provedenih izbora, došlo do primopredaje dužnosti i ustrojavanja nove vlasti. Hrvatskoj je oduzeto naoružanje Teritorijalne obrane (TO) i smješteno u skladišta Jugoslavenske narodne armije (JNA). ${ }^{7}$

Na Srpskom saboru u mjestu Srb, dana 25. srpnja 1990. usvojena je Deklaracija o suverenosti i autonomiji srpskog naroda. Želeći osigurati legalitet pobune i legalitet novih međusobno nepovezanih srpskih oblasti, pobunjeni Srbi pozvali su srpsko stanovništvo u Hrvatskoj na referendumsko izjašnjavanje o ustrojavanju zasebnih srpskih oblasti. Tako je Srpsko nacionalno vijeće (SNV), izvršno tijelo Srpskog sabora, donijelo odluku da se od 19. kolovoza do 2. rujna 1990. provede izjašnjavanje srpskog naroda u RH o srpskoj autonomiji. ${ }^{8}$

Uoči spomenutog izjašnjavanja na državne su prometnice 17. kolovoza 1990. u sjevernoj Dalmaciji (na području Knina, Benkovca i Obrovca) postavljene prepreke (balvan revolucija) te je proglašeno ratno stanje. ${ }^{9}$ Navedeni događaji mogu se shvatiti kao početak oružane pobune Srba protiv demokratski izabrane vlasti u Hrvatskoj s ciljem stvaranja srpske države na dijelu teritorija RH i njezina pripajanja jedinstvenoj srpskoj državi, koja je trebala nastati na većem dijelu teritorija bivše Jugoslavije. ${ }^{10}$

Izjašnjavanje (referendum) o srpskoj autonomiji u Hrvatskoj održano je 19. kolovoza 1990. godine ${ }^{11}$ uz podršku političkih vlasti iz Beograda, te je

${ }^{7}$ Borislav Jović, Poslednji dani SFRJ: Izvodi iz dnevnika (Beograd: Politika, 1995), 146.

${ }^{8}$ Zapisnik 1. sjednice Srpskog nacionalnog vijeća od 31. srpnja 1991, Knin. U: Republika Hrvatska i Domovinski rat 1990.-1995.: Dokumenti, ur. Mate Rupić, knjiga 2 (Zagreb: Hrvatski memorijalno- dokumentacijski centar Domovinskog rata, 2007), 56.

${ }^{9}$ HR-HMDCDR-4. Vlada Republike Srpske Krajine. Odluka Vlade Republike Srpske Krajine (RSK) kojom se utvrđuje da je rat na području RSK počeo 17. kolovoza 1990., a Zakonom o državnim praznicima RSK dan 17. kolovoza proglašen je državnim praznikom RSK - Danom ustanka srpskog naroda (kutija broj 2). Vidi: Nikica Barić, Srpska pobuna u Hrvatskoj 1990.1995. (Zagreb: Golden marketing - Tehnička knjiga, 2005), 77-81.

${ }^{10}$ Barić, Srpska pobuna u Hrvatskoj, 93-99.

${ }^{11}$ HR-HMDCDR-2. Paradržavne i paravojne postrojbe na okupiranom području RH 1990.1995. Izjašnjavanje je održano u općinama Knin, Benkovac, Obrovac, Gračac, Srb, Gospić, Titova Korenica, Otočac, Ogulin, Slunj, Vojnić, Karlovac, Vrginmost, Glina, Dvor, Kostajnica, Petrinja, Pakrac, Daruvar, Grubišno Polje, Garešnica, Beli Manastir i Vukovar, te na dijelovima općina Sinj, Drniš, Skradin, Zadar, Duga Resa, Vrbovsko, Sisak, Karlovac, Novska, Nova Gradiška, Kutina, Bjelovar, Virovitica, Podravska Slatina, Orahovica, Našice, Osijek, Vinkovci, Rijeka, Pula, Imotski, Metković i Dubrovnik (Izvještaj o provođenju izjašnjavanja srpskog naroda u RH o srpskoj autonomiji koji je „Centralna komisija za provođenje izjašnjavanja“" sastavila u Srbu 30. rujna 1990. (kut. 359). Vidi: Barić, Srpska pobuna u Hrvatskoj, 93-96; Mirko Valentić, Rat protiv Hrvatske 1991. - 1995: Velikosrpski projekti od ideje do 
u općinama s većinskim srpskim stanovništvom 30. rujna 1990. proglašena autonomija srpskog naroda u Hrvatskoj, a 21. prosinca 1990. SAO Krajina, koja je obuhvaćala srpske općine sjeverne Dalmacije, Like, Korduna i Banovine. U njoj je vrhovnu izvršnu vlast obnašalo Izvršno vijeće, a zakonodavnu Skupština. SAO Krajina je statutom definirana kao teritorijalna autonomija u sklopu RH i federativne Jugoslavije, ${ }^{12}$ a ubrzo su joj se pridružile općine $\mathrm{s}$ većinskim srpskim stanovništvom (ili značajnom manjinom) na području zapadne Slavonije, SAO Zapadna Slavonija (12. kolovoza 1991.), i općine na području istočne Slavonije, Baranje i zapadnog Srijema, Srpska oblast Slavonija, Baranja i Zapadni Srem (25. rujna 1991.). ${ }^{13}$

Poslije provedenog referenduma, donosila se i odluka o odcjepljenju od RH i odluka o priključenju jednoj od autonomnih oblasti, što je objavljivano u Službenom glasniku Republike Srpske Krajine, svojevrsnim službenim novinama pobunjenih Srba. ${ }^{14}$ Ustavni sud RH poništio je sve odluke vodstva pobunjenih Srba, jer nisu bile u skladu s Ustavom SRH iz 1974. godine. Cijeli postupak nasilno otetih dijelova teritorija RH i stvaranja autonomnih oblasti nedvojbeno je svjedočio o početku provođenja velikosrpskog projekta, tj. želje da svi Srbi žive u jednoj državi. ${ }^{15}$

Izjašnjavanje o autonomiji provedeno je i na području općina Beli Manastir i Vukovar, kao i u dijelovima općina Osijek i Vinkovci. Sredinom veljače

realizacije (Slavonski Brod-Zagreb: Hrvatski institut za povijest - Podružnica za povijest Slavonije, Srijema i Baranje, Hrvatski memorijalno-dokumentacijski centar Domovinskog rata, 2010), 91.

${ }^{12}$ HR-HMDCDR-2. Paradržavne i paravojne postrojbe na okupiranom području RH 1990.1995. Statut „Srpske autonomne oblasti Krajina”, Knin, 21. decembra 1990. (kut. 236).

${ }^{13}$ Izjašnjavanje o srpskoj autonomiji krajem kolovoza i početkom rujna 1990. provedeno je na području zapadne Slavonije u općinama Daruvar, Garešnica, Grubišno Polje i Pakrac, a djelomično i u općinama Bjelovar, Kutina, Nova Gradiška, Novska, Orahovica, Podravska Slatina i Virovitica. Na području istočne Slavonije, Baranje i zapadnog Srijema u općinama Beli Manastir i Vukovar, kao i u dijelovima općina Osijek i Vinkovci. Barić, Srpska pobuna u Hrvatskoj, 98-107. Dokumenti o izdvajanju hrvatskog teritorija i njegova referendumskog uključivanja u srpske autonomne oblasti objavljeni su u: Republika Hrvatska i Domovinski rat 1990.-1995.: Dokumenti institucija pobunjenih Srba u Republici Hrvatskoj (1990.1991.), knjiga 2, ur. Mate Rupić (Zagreb: Hrvatski memorijalno-dokumentacijski centar Domovinskog rata, 2007).

${ }^{14}$ Službeni glasnik Republike Srpske Krajine izlazio je na okupiranom području u razdoblju 1992.-1995., a slijednik je službenih glasila koja su izlazila tijekom 1991. To su: Glasnik Krajine (službeni list Srpske autonomne oblasti Krajina i opština Benkovac, Donji Lapac, Gračac, Knin, Korenica i Obrovac), Srpski glasnik Srpske oblasti Slavonije, Baranje i Zapadnog Srema i Službeni glasnik Opštine Beli Manastir. Sve njih je Službenik glasnik RSK objedinio i kao službeno glasilo pokrivao je područje „Republike Srpske Krajine“.

${ }^{15}$ Ustavni sud RH, broj: U-X-2271/2002, Zagreb, 12. studenoga 2002. Izvješće u povodu inicijative Vlade RH, klasa: 004-01/02-02/12, urudžbeni broj: 5030109-02-2 od 10. listopada 2002. godine. 
1991. najavljeno je održavanje referenduma o izdvajanju jedanaest sela s većinskim srpskim stanovništvom iz općine Vinkovci i njihovo pripajanje općini Vukovar. U Šidskim Banovcima 7. siječnja 1991. osnovano je Srpsko nacionalno vijeće Slavonije, Baranje i zapadnog Srijema (SNV SBZS), koje je 26. veljače 1991. donijelo Deklaraciju o suverenoj autonomiji Srpskog naroda Slavonije, Baranje i Zapadnog Srema.${ }^{16}$ U Deklaraciji se navodi da „suverena srpska autonomija Slavonije, Baranje i Zapadnog Srema postoji i deluje u sastavu sadašnje Republike Hrvatske samo pod uslovom da Jugoslavija postoji kao savezna država“. Ukoliko takva Jugoslavija prestane da postoji ili se preobrazi u skup samostalnih država, ova autonomija nastavit će da postoji kao dio matične države srpskog naroda. ${ }^{17}$

Krajem svibnja 1991. Izvršno vijeće SAO Krajine preimenovano je u Vladu SAO Krajine, pod čijom su se ingerencijom nalazile općine sa srpskom većinom na području sjeverne Dalmacije, Like, Korduna i Banije. Na području SAO Zapadna Slavonija od kolovoza 1991. djeluju Oblasno vijeće i Narodna skupština, a na području Srpske oblasti Slavonija, Baranja i Zapadni Srem, od rujna 1991. do 26. veljače 1992., neovisno o vladi u Kninu, Vlada Srpske oblasti Slavonija, Baranja i Zapadni Srem i Velika narodna skupština Srpske oblasti Slavonija, Baranja i Zapadni Srem. Na zasjedanju Ustavotvorne skupštine SAO Krajine u Kninu, 19. prosinca 1991. godine, proglašena je RSK i usvojen njezin ustav, nakon čega su skupštine SAO Zapadne Slavonije i Srpske oblasti Slavonija, Baranja i Zapadni Srem donijele odluku o ulasku u njezin sastav.

Odluka o proglašenju RSK donesena 19. prosinca 1991. u Kninu, a njome se ujedinjuju srpske autonomne oblasti i srpske oblasti, te predstavlja vrhunac protuustavnog djelovanja Srba u Hrvatskoj, odnosno procesa izdvajanja dijela teritorija RH i proglašenja srpske paradržave. Amandmanom I. na Ustav RSK, proglašenim 26. veljače 1992., određeno je da teritoriju RSK čine srpske oblasti: Krajina, Slavonija, Baranja, Zapadni Srem i Zapadna Slavonija.$^{18} \mathrm{Na}$ temelju spomenutog Ustava RSK, od 1992. do 1995., donesen je niz novih zakona kojima se ustrojavao sustav upravne vlasti i obrane.

\footnotetext{
${ }^{16}$ Službeni glasnik Srpske oblasti Slavonija, Baranja i Zapadni Srem, I, 1/1991.

${ }^{17}$ Isto.

18 Službeni glasnik Republike Srpske Krajine, 2/1992.
} 


\section{Upravno-teritorijalna podjela RSK, stvarna nadležnost stvaratelja i sadržaj arhivskog gradiva}

\subsection{Vlada RSK, Skupština RSK, oblasti i općine}

Na prvoj sjednici Skupštine RSK, održanoj 26. veljače 1992. godine u Borovu Selu, konstituirana je Vlada RSK, koja je do 5. kolovoza 1995. djelovala u pet sastava (19. prosinac 1991. do 26. veljače 1992. - predsjednik Milan Babić/Risto Matković; ${ }^{19}$ 26. veljače 1992. do 20. travnja 1993. - predsjednik Zdravko Zečević; ${ }^{20}$ 20. travnja 1993. do 21. travnja 1994. - predsjednik Đorđe Bjegović; ${ }^{21}$ 21. travnja 1994. do 28. svibnja 1995. - predsjednik Borislav Mikelić; 22 27. srpnja 1995. do 5. kolovoza 1995. - predsjednik Milan Babić). ${ }^{23}$ U Vladi RSK djelovalo je do 21. ožujka 1992. petnaest ministarstava, ${ }^{24}$ a nakon toga sedamnaest. ${ }^{25}$ Djelokrug nadležnosti Vlade RSK kao najvišeg tijela izvršne vlasti paradržave RSK od 1991. do 1995. određen je Zakonom o Vladi RSK iz 1992. te Zakonom o izmjenama i dopunama Zakona o Vladi RSK iz 1994. Vlada RSK prestala je djelovati 5. kolovoza 1995. kada su hrvatske postrojbe, u sklopu vojno-redarstvene operacije Oluja, oslobodile njezino dotadašnje upravno sjedište Knin.

Arhivski fond Vlade RSK sadrži zapisnike sjednica s odlukama i rješenjima koja su pritom donesena, uredbe, pravilnike, nacrte i prijedloge zakona,

${ }_{19}$ Srpske novine, 5-6/1992.

${ }^{20}$ Službeni glasnik Republike Srpske Krajine, 2/1992.

${ }^{21}$ Službeni glasnik Republike Srpske Krajine, 3/1993.

${ }^{22}$ Službeni glasnik Republike Srpske Krajine, 8/1994; Krajina magazin, 5/1995. Opširnije u: Slaven Ružić, Djelovanje ,,Vlade Republike Srpske Krajine“ 1991.-1995. (Zagreb: Hrvatski memorijalno-dokumentacijski centar Domovinskog rata, 2017).

${ }^{23}$ Barić, Srpska pobuna u Hrvatskoj, 585-590.

${ }^{24}$ Ministarstvo odbrane, Ministarstvo unutrašnjih poslova, Ministarstvo inostranih poslova, Ministarstvo finansija, Ministarstvo pravosuđa i uprave, Ministarstvo industrije i ekonomskog razvoja, Ministarstvo poljoprivrede, šumarstva, vodoprivrede, turizma i trgovine, Ministarstvo elektroprivrede i energetike, Ministarstvo prometa i veza, Ministarstvo za urbanizam, stambeno-komunalne poslove i građevinarstvo, Ministarstvo obrazovanja, Ministarstvo prosvjete, kulture i fizičke kulture, Ministarstvo zdravstva, socijalnog rada i socijalne politike, Ministarstvo informisanja, Ministarstvo vjera.

${ }^{25}$ Ministarstvo odbrane, Ministarstvo unutrašnjih poslova, Ministarstvo vanjskih poslova, Ministarstvo finansija, Ministarstvo trgovine i turizma, Ministarstvo poljoprivrede, šumarstva i vodoprivrede, Ministarstvo pravosuđa i uprave, Ministarstvo zdravlja i zdravstvenog osiguranja, Ministarstvo informiranja, Ministarstvo za ekonomske odnose, privredni razvoj i industriju, Ministarstvo prosvjete, Ministarstvo kulture i vjera, Ministarstvo fizičke kulture i sporta, Ministarstvo za urbanizam, stambeno-komunalne poslove i građevinarstvo, Ministarstvo za promet i veze, Ministarstvo energetike i rudarstva, Ministarstvo za rad, boračka i socijalna pitanja. 
dok je gradivo pripadajućih ministarstava zbog svoje fragmentarnosti sređeno kao zaseban podfond (s ukupno petnaest serija). Izuzetak čine fondovi Ministarstva odbrane i Ministarstva unutrašnjih poslova RSK, koji zbog svoje količine i cjelovitosti čine zasebne fondove. Gradivo pojedinih stručnih povjerenstava i komiteta koje je osnovala Vlade RSK oblikovano je u četiri podserije.

U ustroju vlasti, Skupština RSK predstavljala je najviše zakonodavno tijelo, a za svoj rad bili su joj odgovorni Vlada RSK i predsjednik RSK. Skupština je birala i razrješavala ministre, suce Ustavnog i Vrhovnog suda, javne tužitelje i guvernera Narodne banke. ${ }^{26}$

Prema Zakonu o teritorijalnoj organizaciji RSK i lokalnoj upravi od 21. ožujka 1992., određeno je da teritorijalnu organizaciju čine općine (tijela lokalne uprave) i tri srpske oblasti: Krajina (bivša SAO Krajina), Zapadna Slavonija te Slavonija, Baranja i Zapadni Srem. Općinska uprava dijelila se na općinsku skupštinu i izvršno vijeće (izvršni savjet):

- Dalmacija: općina Knin (i glavni grad RSK), Benkovac, Drniš, Obrovac, Srpska općina Zadar,27

- Lika: Korenica, Donji Lapac, Gračac, Plaški, Vrhovine; Kordun: Slunj, Vojnić, Vrginmost i Krnjak; Banija: Petrinja, Glina, Kostajnica, Dvor na Uni i Sisak-Caprag;

- zapadna Slavonija: Okučani (novoustrojena od srpskog istorijskog $i$ etničkog prostora Novske i Nove Gradiške), Pakrac (čija je površina delom na teritoriji Hrvatske), ${ }^{28}$ Grubišno Polje, Daruvar i Podravska Slatina (koje se nalaze na teritoriji koja je pod kontrolom hrvatske vlasti);

- istočna Slavonija, Baranja i zapadni Srijem: Vukovar, Beli Manastir, Tenja, Dalj, Mirkovci.

Srpska oblast Slavonije, Baranje i Zapadnog Srema kao tijela vlasti imala je Veliku narodnu skupštinu i Oblasno vijeće, a Srpska oblast Zapadna Slavonija Narodnu skupštinu i Oblasno vijeće. Općinske uprave (izvršni savjeti općina) na području sjeverne Dalmacije, Like, Korduna i Banije bile su izrav-

\footnotetext{
${ }^{26}$ Službeni glasnik Republike Srpske Krajine, 1/1992.

${ }^{27}$ Osnivačka skupština Srpske općine Zadar održana je 16. travnja 1993. u Kninu. Ona je trebala predstavljati Srbe koji su izbjegli iz grada Zadra, kao i one koji su početkom 1993., nakon hrvatske vojne akcije "Maslenica", napustili svoje domove u zadarskom zaleđu. Za gradonačelnika srpskog Zadra izabran je politolog Mladen Kalapać. Srpska općina Zadar uputila je molbu talijanskom veleposlanstvu u Beogradu da sudjeluje u "rješavanju pitanja grada Zadra”. Vlada RSK je 17. veljače 1994. donijela odluku o imenovanju Izvršnog savjeta srpske općine Zadar pod predsjedanjem Kalapaća. Barić, Srpska pobuna u Hrvatskoj, 173. Vidi: Službeni glasnik Republike Srpske Krajine, 2/1994.

${ }^{28}$ Barić, Srpska pobuna u Hrvatskoj, 174.
} 
no podređene Vladi RSK, za razliku od srpskih oblasti u zapadnoj i istočnoj Slavoniji (s Baranjom i Zapadnim Srijemom), koje su imale oblasne vlade, odnosno oblasna vijeća. ${ }^{29}$

\subsection{Pravosuđe}

Ustroj pravosudnog sustava u RSK bio je pod resornim ministarstvom pravosuđa i uprave. Na temelju Zakona o sudovima ${ }^{30}$ sudovi su organizirani kao sudovi opće nadležnosti i privredni sudovi. Sudovi opće nadležnosti bili su općinski sudovi, okružni i Vrhovni sud. Druga instanca kod privrednih/gospodarskih sudova bio je Viši privredni sud. Općinski sudovi bili su osnivani na teritoriju jedne ili više općina (Knin, Vukovar, Beli Manastir, Pakrac, Benkovac, Obrovac, Gračac, Korenica, Kostajnica, Okučani, Vojnić, Vrginmost, Glina, Petrinja, Dvor na Uni, Donji Lapac), a okružni sudovi za područje dvaju ili više općinskih sudova (sjedišta Knin, Beli Manastir, Pakrac, Glina). Privredni su u svojoj nadležnosti obuhvaćali teritorij više općina, a Viši privredni sud teritorij RSK. Najviša instanca bio je Vrhovni sud (Knin). Privredni sudovi djelovali su kao odjeli unutar okružnih sudova. Tužiteljstva kao općinska sjedišta ustrojena su u Vukovaru, Belom Manastiru, Kninu, Benkovcu, Korenici, Glini, Okučanima, a kao okružna u Belom Manastiru, Kninu i Glini. U većim općinskim mjestima osnovano je četrnaest prekršajnih sudova.

\subsection{Ministarstvo odbrane RSK i Sekretarijat unutrašnjih poslova (SUP)}

Prema Zakonu o odbrani RSK od 21. ožujka 1992., Ministarstvo odbrane bilo je nadležno za poslove vojne obveze i mobilizacije, kao i mobilizaciju državnih organa i jedinica i štabova civilne zaštite, te je djelovalo preko svojih područnih uprava za obranu: za sjevernu Dalmaciju (sjedište u Kninu), Liku (sjedište u Korenici), Baniju (sjedište u Petrinji), Kordun (sjedište u Vojniću), zapadnu Slavoniju (sjedište u Okučanima), istočnu Slavoniju, Baranju i zapadni Srijem (sjedište u Erdutu). Upravama su bila podređena općinska odjeljenja za odbranu, odnosno u manjim općinama postojali su odsjeci za odbranu. Gradivo ministarstva, područnih ureda, općinskih odjeljenja i odsjeka sadrži zapise o novačenju, mobilizaciji, ratnim sistematizacijama i dobrovoljcima iz Savezne Republike Jugoslavije (SRJ) i Republike Srpske (RS).

Dana 4. siječnja 1991. osnovan je i Sekretarijat unutrašnjih poslova SAO Krajine (SUP SAO Krajine), koji je na području Krajine brinuo za državnu i javnu sigurnost i ostale unutarnje poslove policijske naravi. ${ }^{31}$ Sjedište SUP-a bilo je u Kninu, a policijske su postaje osnovane u mjestima Benkovac, Donji

\footnotetext{
${ }^{29}$ Službeni glasnik Republike Srpske Krajine, 2/1992.

${ }^{30}$ Službeni glasnik Republike Srpske Krajine, 4/1992.

${ }^{31}$ Barić, Srpska pobuna u Hrvatskoj, 105.
} 
Lapac, Dvor na Uni, Gračac, Glina, Kostajnica, Obrovac, Titova Korenica, Vojnić i Knin (Uredba o unutrašnjoj organizaciji i radu SUP-a SAO Krajine od 19. siječnja 1991.). ${ }^{32}$

U svibnju 1991. ustrojavaju se i jedinice za specijalne namjene u svrhu obrane teritorijalnog integriteta Krajine i osiguranja njezinih objekata i ustanova (Milicija Krajine) i bile su podređene Ministarstvu odbrane. Potrebno je istaknuti da je SUP SAO Krajine tijekom 1991. većinu svojih organizacijskih i ljudskih potencijala koristio u borbama s hrvatskim oružanim snagama, a samo dio za održavanje javnog reda i mira kao glavnog policijskog zadatka. To potvrđuje i naredba predsjednika Vlade SAO Krajine od 9. listopada 1991. kojom se naređuje da sve krajinske jedinice policije u planiranju i izvršavanju borbenih zadataka budu podređene nadležnim zapovjednicima TO. ${ }^{33}$

Nova organizacija tijela unutarnjih poslova RSK provedena je nakon potpisivanja Vanceovog mirovnog plana, u siječnju 1992. ${ }^{34}$ Djelokrug rada određen je Zakonom o unutrašnjim poslovima od 26. veljače 1992. Kao područne organizacijske jedinice ustrojeni su oblasni centri bezbjednosti, u Kninu za područje sjeverne Dalmacije i Like, u Glini za područje Banije i Korduna, u Pakracu (s privremenim sjedištem u Okučanima) za područje zapadne Slavonije, u Vukovaru (s privremenim sjedištem u Dalju) za područje istočne Slavonije i zapadnog Srijema, te u Belom Manastiru za područje Baranje. Zakonom o izmenama i dopunama Zakona o unutrašnjim poslovima oblasni centri bezbjednosti preimenovani su u sekretarijate unutrašnjih poslova (SUP), te se povećao i njihov broj: SUP Knin za područje sjeverne Dalmacije, SUP Korenica za područje Like, SUP Glina za područje Banije, SUP Vojnić za područje

${ }^{32}$ HR-DASK-SACPE-610. Skupština općine Dvor, Uredba o unutrašnjoj organizaciji rada Sekretarijata za unutrašnje poslove, Izvršno vijeće SAO Krajine, Broj: 09/91-1, Knin, 19. 01. 1991. (kut. 2).

${ }^{33}$ Barić, Srpska pobuna u Hrvatskoj, 343-344.

${ }^{34}$ U Sarajevu su 2. siječnja 1992., uz posredovanje Cyrusa Vancea, osobnoga izaslanika glavnog tajnika Ujedinjenih naroda, predstavnici RH i JNA potpisali sporazum o potpunom prekidu vatre u RH. Sporazum se temeljio na dogovoru o deblokadi vojarni JNA i povlačenju JNA iz Hrvatske, te primjeni mirovnoga plana UN-a (predviđao je dolazak mirovnih snaga UN-a u Hrvatsku), a 23. studenoga 1991. u Ženevi potpisali su ga predsjednik Hrvatske Franjo Tuđman, predsjednik Srbije Slobodan Milošević i general JNA Veljko Kadijević uz posredovanje predstavnika UN-a Cyrusa Vancea i predstavnika Europske Zajednice lorda Petera Carringtona. Primjenom Sarajevskog primirja odnosno Vanceova plana u Hrvatskoj prestaju veći ratni sukobi i započinje razdoblje aktivnije međunarodne političke i vojne nazočnosti u Hrvatskoj, koja je, doduše, utjecala na relativno smirivanje prilika, ali ne i na postizanje trajnog i pravednog političkog rješenja. To je razdoblje zaštitnih snaga $\mathrm{UN}-\mathrm{a}$ (UNPROFOR-a) i operacija UN-a za obnovu povjerenja u Hrvatskoj (UNCRO-a), i to od proljeća 1992. do svibnja, odnosno kolovoza 1995. godine. Ana Holjevac Tuković, „Hrvatski istok kroz djelovanje mirovnih misija Ujedinjenih naroda u Domovinskom ratu“, u: Hrvatski istok u Domovinskog rata-iskustva, spoznaje i posljedice: Zbornik Instituta Ivo Pilar. Knjiga 48. (Zagreb: Institut društvenih znanosti Ivo Pilar, Područni centar Osijek, 2015), 121-141. 
Korduna, SUP Pakrac (sa sjedištem u Okučanima) za područje zapadne Slavonije, SUP Vukovar (s privremenim sjedištem u Dalju) za područje istočne Slavonije i zapadnog Srijema, te SUP Beli Manastir za područje Baranje.

Gradivo sadrži naredbe, službene bilješke, zapisnike, izvještaje o radu, izvještaje s terena, odobrenja za nesmetani ulazak i boravak na području RSK, odobrenja za napuštanje područja RSK, zapise vezane uz zaštitne snage Ujedinjenih naroda (UN) (United Nations Protecion Forces - UNPROFOR-a), saznanja o aktivnostima Hrvatske vojske, spise o školovanju pripadnika milicije i personalne spise.

U travnju 1993. uvedena je institucija Vrhovnog savjeta obrane RSK, u čijem su sastavu bili predsjednik RSK, predsjednik Vlade, ministar obrane, ministar unutrašnjih poslova i komandant Glavnog štaba Srpske vojske Krajine (SVK). Ovo tijelo trebalo je utvrditi stanje neposredne ratne opasnosti i proglasiti ratno stanje u slučaju da je u tome Skupština RSK spriječena. Osim toga, Vrhovni savjet obrane donosio je i odluke o pripravnosti, mobilizaciji i upotrebi SVK. Fond sadrži dokumente koji se odnose na procjenu sigurnosne i vojne situacije RSK, kao i planove za ratna djelovanja.

\subsection{Srpska vojska Krajine (SVK)}

Oružane snage pobunjenih Srba nastale su najvećim dijelom na postojećoj bazi organizacije unutarnjih poslova i narodne obrane, odnosno njihov ustroj temeljio se na strukturi TO, ali postupci ustrojavanja postrojbi i ustanova te pozivanja ljudstva na oružje bili su različiti u pojedinim pobunjeničkim krajevima. U ljeto 1991. pobunjeni Srbi intenziviraju ustrojavanje vojnih postrojbi. Milan Babić, predsjednik Vlade i ministar obrane SAO Krajine, izdao je 11. srpnja 1991. naredbu o mobilizaciji svih štabova i jedinica TO na teritoriju SAO Krajine, ${ }^{35}$ te se osnivaju općinski i regionalni štabovi i postrojbe. Osnova za daljnji ustroj bio je Zakon o obrani Republike Srbije, koji je Vlada SAO Krajine dana 1. kolovoza 1991. prihvatila za teritorij SAO Krajine: TO i jedinice za posebne namjene SUP „Krajine“ sačinjavaju oružane snage SAO Krajine. No, bez pomoći JNA pobunjeni Srbi nisu mogli ustrojiti oružanu silu koja bi bila u stanju realizirati postavljene vojne ciljeve. Od ljeta 1990. do jeseni 1991. oružane formacije pobunjenih Srba činile su odmetnuta policija i lokalna prostorna struktura TO Hrvatske koja nije priznavala hrvatsku vlast. U rujnu 1991. počela je strateška ofenziva JNA na Hrvatsku, u sklopu koje je JNA preuzela nadzor nad oružanim sastavima pobunjenih Srba. Odlukom saveznog sekretara za narodnu odbranu SFRJ, dana 30. rujna 1991. osnovan

${ }^{35}$ Ustavni sud RH, Izvješće u povodu Inicijative Vlade Republike Hrvatske, klasa: 004-01/0202/12, urudžbeni broj: 5030109-02-2 od 10. listopada 2002. Naredba o mobilizaciji svih štabova i jedinica Teritorijalne odbrane na teritoriji Srpske Autonomne Oblasti Krajine, broj: 142/91-3, Knin, 11. jula 1991. godine. 
je Štab TO SAO Krajine, čime je zapravo već postojeći Štab TO SAO Krajine uklopljen u sustav zapovijedanja oružanih snaga SFRJ. JNA je osigurala i personalnu potporu šaljući oficire i podoficire. Tijekom kolovoza i rujna 1991. nastavljeno je organiziranje snaga TO, na čijem čelu se nalazio Štab TO SAO Krajine u Kninu. Osim TO i policije, na strani srpskih pobunjenika djeluju i različite paravojne i dobrovoljačke skupine. ${ }^{36}$

U kolovozu su od regionalnih štabova osnovane tri operativne zone TO SAO Krajine: za sjevernu Dalmaciju, Liku te Kordun i Baniju. Pod zapovjedništvom Prvog zonskog štaba (Dalmacija) bili su Općinski štab TO Knin s brigadom TO Knin i brigadom TO Bukovica, Općinski štab TO Benkovac s brigadom TO Benkovac i Općinski štab TO Obrovac s odredom TO Obrovac; pod zapovjedništvom Drugog zonskog štaba (Lika) bili su Općinski štab TO Korenica s brigadom TO Korenica i odredom TO Plaški, Općinski štab TO Gračac s brigadom TO Gračac, Općinski štab TO Donji Lapac s odredom TO Donji Lapac i 1. brigadom TO Sveti Rok; a pod zapovjedništvom Trećeg zonskog štaba TO (Banija i Kordun) Općinski štab TO Vojnić s brigadom TO Vojnić, Općinski štab TO Vrginmost s brigadom TO Vrginmost, Općinski štab TO Glina s brigadom TO Glina, Općinski štab TO Kostajnica s brigadom TO Kostajnica (7. brigada TO Kostajnica), Općinski štab TO Dvor na Uni s brigadom TO Dvor na Uni, Općinski štab TO Petrinja s brigadom TO Petrinja i Općinski štab TO Sisak s brigadom TO Sisak.

TO je bila ustrojena u štabove, odrede, čete i vodove (tri zonska štaba s pripadajućim prištabskim jedinicama, trinaest općinskih štabova s pripadajućim prištabskim jedinicama, trinaest brigada i tri odreda). ${ }^{37}$

Ustroj TO na području Slavonije bio je drugačiji. Hijerarhijski najviše zapovjedno tijelo bio je Štab TO SAO Zapadna Slavonija, koji je zapovijedao podređenim štabovima i jedinicama u borbenim djelovanjima ${ }^{38}$ (općinski štabovi: Okučani, Pakrac, Daruvar, Grubišno Polje, Podravska Slatina, Slavonska Požega, Novska). ${ }^{39}$ Važno je napomenuti da su sjedišta pojedinih brigada bila samo nominalna, budući da ih snage SVK nisu uspjele okupirati. Sjedišta su zato smještena u druga, obližnja mjesta na okupiranom području, iako se u

${ }^{36}$ Davor Marijan, Hrvatsko ratište 1990. - 1995.: Stvaranje hrvatske države i Domovinski rat (Zagreb: Školska knjiga, 2006), 104.

${ }^{37}$ Milisav Sekulić, Knin je pao u Beogradu (Bad Vilbel: Nidda Verlag GmbH, 2000), 34.

${ }^{38}$ HR-HMDCDR-26. Štab teritorijalne obrane Zapadne Slavonije, Saopštenje za javnost, bez broja i datuma.

${ }^{39}$ Isto, Štab Zapadne Slavonije, Opštinski štab TO Pakrac, Daruvar, Podravska Slatina, Grubišno Polje, Okučani, odred TO Zvečevo, odred TO Miokovićevo, Bučje, OpŠTO Novska i komanda brigade. 
zapisima kao sjedišta najčešće navode upravo ta nominalna mjesta ${ }^{40}$ Tako je, primjerice, stvarno sjedište 59. odreda bilo u Brusniku, a ne u Daruvaru, sjedište 63. odreda u Šumetlici, a ne u Podravskoj Slatini, a sjedište Bataljuna za intervencije nalazilo se u Ivanovcu, a ne u Okučanima. Osim brigada i odreda, ustrojene su i Tenkovska četa sa sjedištem u Staroj Gradišci, Komanda stana, Četa vojne policije, Četa veze, Izviđačka četa (Izviđačko-diverzantski odred), Vod atomsko-biološko-hemijskog obezbeđenja, Komanda dopunskog bataljona, Odelenje S-2M te Odelenje za izlaganje situacije u vazduhu.$^{41}$ Prema dokumentima, Štab TO Zapadne Slavonije nalazio se u Pakracu, a u Zvečevu izdvojeno zapovjedno mjesto. Na tom je prostoru, pored Štaba, djelovalo 7 općinskih štabova, a jedinice TO bile su organizirane u 10 bataljuna, 42 čete i 1 samostalni odred (ukupno 7000 pripadnika). ${ }^{42}$ Godine 1992. (prema zapovijedi saveznog sekretara za narodnu odbranu od 24. ožujka) osnovani su 61. haubičko artiljerijski divizion, 83. mješoviti protuoklopni artiljerijski divizion, 45. lakoartiljerijska baterija protuvazdušne obrane i 91. pozadinska baza $\mathrm{TO}^{43}$

U istočnoj Slavoniji, Srijemu i Baranji lokalna TO službeno je već u prvoj polovici listopada pripojena oružanim snagama SFRJ. Zonski štab TO za istočnu Slavoniju, Baranju i zapadni Srijem osnovan je tek u prosincu 1991., nakon proglašenja RSK. U studenom su općinski štabovi TO preustrojeni (umjesto odreda ustrojene su brigade, njih dvadeset i jedna). Novoustrojene brigade operativno su bile podređene JNA, koja je preuzela njihovu opskrbu. ${ }^{44}$

S dolaskom snaga UN-a u Hrvatsku, vodstvo RSK, pod zapovjedništvom Generalštaba JNA (Vojske Jugoslavije/VJ) iz Beograda, počelo je reorganizirati snage TO. Krajem veljače 1992. Štab TO SAO Krajine u Kninu preimenovan je u Glavni štab TO RSK, kojem je bilo podređeno šest zonskih štabova (ZnŠTO): ${ }^{45}$ ZnŠTO Sjeverna Dalmacija, ZnŠTO Lika, ZnŠTO Kordun, ZnŠTO Banija, ZnŠTO Zapadna Slavonija, ZnŠTO Istočna Slavonija, Zapad-

${ }^{40}$ Julija Barunčić Pletikosić, Željka Križe Gračanin, „Ustroj i djelovanje 18. korpusa Srpske vojske Krajine“, u: Srpska pobuna u zapadnoj Slavoniji 1990. - 1995. (Slavonski Brod Zagreb: Hrvatski institut za povijest - Podružnica za povijest Slavonije, Srijema i Baranje; Hrvatski memorijalno-dokumentacijski centar Domovinskog rata, 2012), 166.

${ }^{41}$ Isto.

${ }^{42}$ HR-HMDCDR-26. Štab teritorijalne obrane Zapadne Slavonije, br. 26/91, 16. 10. 1991., izvještaj, str. 1.

${ }^{43}$ Republika Hrvatska i Domovinski rat 1990.-1995: Dokumenti institucija pobunjenih Srba u Republici Hrvatskoj (1990.-1991.). Knjiga 3., ur. Mate Rupić (Zagreb: Hrvatski memorijalno-dokumentacijski centar Domovinskog rata, 2007), 352.

${ }^{44}$ Isto, 106.

${ }^{45}$ Zapovijed Saveznog sekretara za narodnu odbranu Glavnom Štabu TO RSK za organizacijsko-formacijske promjene u jedinicama TO RSK od 27. veljače 1992. Republika Hrvatska $i$ Domovinski rat 1990.-1995. Knjiga 3, str. 254. 
ni Srem i Baranja, ${ }^{46}$ a krajem 1992. TO RSK preimenovana je u Srpsku vojsku RSK (SV RSK), odnosno Srpsku vojsku Krajine (SVK). U skladu s time Glavni štab TO RSK preimenovan je u Glavni štab SVK. Gradivo Glavnog štaba SVK iznimno je opsežno i sadrži podatke strateškog, operativnog i taktičkog značaja (naredbe, osobni spisi, operativni i borbeni izvještaji, nastavni planovi i programi, izvještaji korpusa SVK i korpusa Vojske Republike Srpske (VRS) upućeni Glavnom štabu SVK). ${ }^{47}$

ZnŠTO preimenovani su u korpuse SVK (ZnŠTO Sjeverna Dalmacija u 7. sjevernodalmatinski korpus, ZnŠTO Lika u 15. lički korpus, ZnŠTO Kordun u 21. kordunski korpus, ZnŠTO Banija u 39. banijski korpus, ZnŠTO Zapadna Slavonija u 18. zapadnoslavonski korpus i ZnŠTO Istočne Slavonije, Baranje i Zapadnog Srema u 11. slavonsko-baranjski korpus). Izvršena je i reorganizacija i preimenovanje jedinica i štabova podređenih dotadašnjim zonskim štabovima TO. Ukinuti su općinski štabovi koji su djelovali od 1991. i brigade posebne jedinice milicije, ali bataljuni ovih brigada ušli su u sastav brigada SVK. ${ }^{48}$ Gradivo korpusa sadrži zapovijedi, dnevne redovne i borbene izvještaje, izvještaje podređenih jedinica, vojne planove, planove rada i obuke, sheme strukture jedinica, obavještajne podatke, personalne spise, osobnike, radne liste, rješenja, redne liste, medicinsku dokumentaciju, podatke o postavljanjima, razrješenjima i unapređenjima, obavještajne i sigurnosne podatke, ratne planove, borbena i dnevna izvješća podređenih jedinica te izvješća pojedinih organa i službi Komande, mobilizacijske spise, personalne spise (ugovore, molbe, osobnike, rješenja o postavljanju, potvrde, popise pripadnika, popise isplaćenih naknada) i financijska izvješća.

${ }^{46}$ Imena komandanta zonskih štabova TO dana su prema stanju iz lipnja 1992. godine. Vidjeti: „RSK“, Glavni štab Teritorijalne odbrane, Str. Pov. Br. 636-1, 18. 06. 1992. DASK, SAC Petrinja, Zonski štab TO Kordun, SP br. 768-28, 19. 06. 1992.

${ }^{47}$ HR-HMDCDR-6. Glavni štab Srpske vojske Krajine. Sadržaj dokumenata odnosi se i na planove rada, programe, informacije za javnost, prijedloge plana popune, planove transformacije SVK, odobrenja, organizacijsko-formacijske promjene SVK, informacije podčinjenim jedinicama, informacije o NATO-u, UNPROFOR-u i hrvatskim snagama, analize, obavijesne informacije, zahtjeve za popunu ljudstvom i zahtjeve za materijalno-tehničkim sredstvima, dokumente obavijesne i sigurnosne tematike, obavještajne izvještaje, sigurnosna zapažanja, dokumente sigurnosno-operativnih akcija, planove metode rada, podatke o novinarima, pripadnicima SVK, pripadnicima hrvatskih snaga, pripadnicima UN-a, građanima RSK, kontraobavještajne procjene, pozivanje djelatnih vojnih osoba iz VJ, raznu osobnu dokumentaciju upućenu GŠ SVK, informacije za psihološko-promidžbenu aktivnost, organiziranje sportskih natjecanja, izvještaje o stanju morala, članke za list Vojska Krajine, informacije Press centra GŠ SVK, vijesti Hrvatskoga radija, odobrenja za odlazak na teren novinarima, prijedloge za organizaciju i funkcioniranje Press centra GS̆ SVK, konferencije za tisak i informacije za javnost o stanju na ratištu i raznim političkim događanjima u RSK.

${ }^{48}$ Sekulić, Knin je pao u Beogradu, 35-38. 
Nakon vojno redarstvene operacije Bljesak, tijekom svibnja i lipnja 1995. osnovan je i Korpus specijalnih jedinica, ${ }^{49}$ koji je trebao povećati borbenu snagu SVK i ojačati obranu RSK u slučaju novog hrvatskog napada. U svom sastavu imao je Oklopnu brigadu, Gardijsku brigadu i Izviđačko-diverzantski odred.

Potrebno je napomenuti da arhivsko gradivo koje se odnosi na područje hrvatskog Podunavlja, odnosno stvaratelja Srpske oblasti Slavonija, Baranja i Zapadni Srem i 11. korpusa SVK nije, poput onog iz ostalih dijelova RSK, zaplijenjeno, nego je za vrijeme reintegracije uništeno ili prenijeto u Srbiju. Dokumentacija vlade RSK u Erdutu nestala je iz objekta Vinarije Erdut. Isto se dogodilo i s dokumentacijom pojedinih tijela vlasti RSK čija su sjedišta bila u lokalnim mjestima, tako da je gradivo s područja hrvatskog Podunavlja fragmentarno sačuvano. Ono što je sačuvano, u pravilu je izdvojeno iz gradiva stvaratelja opsegom većih arhivskih fondova srpske provenijencije. ${ }^{50}$ Gradivo 11. korpusa SVK fragmentarno je sačuvano, a sadrži gradivo Zapovjedništva 11. K - Vukovar / Borovo selo VP 9189, Obavještajno-sigurnosne službe 11. K i Vojnog odsjeka Vukovar. Djelomično je sačuvano i gradivo korpusu podređenih postrojbi: $35 ., 40 ., 43$. i 45 . pješadijske brigade te 1 . baranjske divizije.

$\mathrm{Za}$ analizu i organizacijsku strukturu korpusa SVK bitan je dokument Glavnog štaba SVK pod nazivom Pregled brojnih veličina organizacijskoformacijske strukture SVK iz travnja 1994., s brojčanim podacima o pripadnicima i veličini površine teritorija za koji je pojedini korpus bio odgovoran. Korpusi su u pravilu brojili između 3000 i 3400 pripadnika (izuzetak predstavljaju 18. korpus s 2058 pripadnika i 7. korpus s 5170 pripadnika), ${ }^{51}$ a pokrivali su površinu između $587 \mathrm{~km}^{2}$ (18. korpus) i od 2300 do $4900 \mathrm{~km}^{2}$ (ostali korpusi). Podaci o površini koji se navode u tom dokumentu odstupaju od podatka o ukupnoj površini RSK iznesenog na sjednici Vlade RSK od 29. srpnja 1992.: "RSK obuhvata prostor od 13.913 km" (vjerojatno prostor Zone

${ }^{49}$ HR-HMDCDR-27. Vrhovni savjet obrane „RSK“. Koncept nove organizacije i formiranje SVK; zapovijed Mile Mrkšića, zapovjednika SVK, za preustroj SVK i stvaranje suvremenije i organiziranije vojske, nakon poraza u zapadnoj Slavoniji, koji je pokazao njezine slabosti, prije svega nefunkcionalnost i neadekvatnost organizacijsko-formacijske strukture jedinica $i$ komandi (kut. 1). Vidi: Republika Hrvatska i Domovinski rat 1990.-1995.: Dokumenti institucija pobunjenih Srba u Republici Hrvatskoj ( svibanj - listopad 1995.). Knjiga 17., ur. Ivan Brigović, Natko Martinić Jerčić, Ivan Radoš (Zagreb: Hrvatski memorijalno-dokumentacijski centar Domovinskog rata, 2007), 91.

${ }^{50}$ Ivica Ćosić i Marko Landeka, „Štete na arhivskom gradivu u Podunavlju za vrijeme agresije na Hrvatsku od 1991. do 1998. godine“, Glasnik arhiva Slavonije i Baranje 5 (1999), 183-192.

${ }^{51}$ HR-HMDCDR-6. Glavni Štab Srpske vojske Krajine, Pregled brojnih veličina organizacijsko-formacijske strukture SVK - prijedlog, april 1994., strogo povjerljivo pov. 30-34. 
pod zaštitom Ujedinjenih naroda, United Nations Protected Areas (UNPA) i ružičastih zona), te da se sastoji iz dvije međusobno odvojene cjeline - koje čine „Sjeverna Dalmacija, Lika, Kordun, Banija i Zapadna Slavonija ukupne površine $11.402 \mathrm{~km}^{2}$ i Istočna Slavonija, Zapadni Srem i Baranja ukupne površine $2511 \mathrm{~km}^{26}{ }^{25}$ Može se zaključiti da su podaci o veličini teritorija pod nadzorom korpusa, kao i izvješća o borbenoj i moralnoj spremnosti, često prikrivali stvarno stanje. Sam vojni ustroj od svibnja 1992. pa do kolovoza 1995. (ustrojbena organizacija zonskih štabova i korpusa) tek se neznatno razlikovao od formacijskih rješenja koje je ranije postavila JNA, pri čemu su taktičke postrojbe (bataljuni i brigade) samo mijenjale nazive. Područja pod vojnom nadležnošću korpusa nisu bila ujednačena, nego su ustrojena na temelju količine oružja i opreme koje je ostavila JNA i brojnosti raspoloživog ljudstva.

Gradivo vojne provenijencije opsežno je i nije u potpunosti sređeno, ali arhivski su fondovi oblikovani prema organizacijskoj strukturi oružanih snaga. Za dio se gradiva (na temelju njegovog većeg opsega), zbog svoje upletenosti u događanja na okupiranom teritoriju RH, kao stvaratelj navodi JNA, odnosno VJ, dok je jedan dio dokumentacije (specifične vrste zapisa) oblikovan u arhivske zbirke: Zbirka vojnih zemljovida, Zbirka pečata vojnih postrojbi, Zbirka rokovnika, Zbirka vojnih knjižica i iskaznica te Zbirka vojnih kartona. ${ }^{53}$

\section{Gospodarska djelatnost na okupiranim području kroz fondove RSK}

Ratni događaji iz 1991. bili su za krajinske Srbe razdoblje u kojem se prekidaju sve gospodarske veze s drugim dijelovima Hrvatske i potpuno se preorijentiraju i usmjeravaju prema Republici Srbiji, bez obzira na njezinu udaljenost i nepostojanje izravne veze sa zapadnim dijelovima Krajine. Takvim razvojem događaja okupirana područja ovisila su o pomoći iz Srbije, osobito u energentima i industrijskoj robi, iako su pobunjeni Srbi 1991. zaposjeli izvore nafte $u$ istočnoj Slavoniji, koji su pokrivali njihove potrebe za gorivom (,vlastiti izvori“), štoviše da njihovom nekontroliranom eksploatacijom čak izvoze naftne derivate. Zakon o osnutku Javnog poduzeća za istraživanje, proizvodnju, preradu i promet nafte i prirodnog plina, a koje je nazvano „Naf-

${ }^{52}$ HR-HMDCDR-4. Vlada „Republike Srpske Krajine“, Zapisnik 25. sjednice Vlade Republike Srpske Krajine od 29. srpnja 1992., kut. 3.

${ }^{53}$ Ilija Vučur i Janja Sekula, „Pregled arhivskoga gradiva vojne provenijencije „Republike Srpske Krajine" u Hrvatskome memorijalno-dokumentacijskom centru Domovinskoga rata i državnim arhivima Republike Hrvatske“", u: Arhivi i Domovinski rat, 49. savjetovanje hrvatskih arhivista, 26. - 28. listopada 2016. Plitvice, ur. Silvija Babić (Zagreb: Hrvatsko arhivističko društvo, 2016), 45-51. 
tna industrija Krajine“ (NIK), proglašen je 18. svibnja 1992. ${ }^{54}$ Sjedište tvrtke bilo je u Mirkovcima u istočnoj Slavoniji, a ona je držala upravu nad poduzećima za prodaju nafte i njezinih derivata u cijeloj RSK, kao i nad prirodnim izvorima nafte i plina u općini Mirkovci. NIK je definiran kao javno poduzeće od posebnog značenja te se nalazio pod izravnom upravom krajinske Vlade, koja je preko Upravnog odbora trebala nadzirati rad tvrtke. Poduzeće je raspolagalo s ukupno 36 bušotina u Đeletovcima, Ilači i Srijemskim Lazama. ${ }^{55}$ Gradivo arhivskog fonda NIK Krajine sadrži podatke o proizvodnji derivata nafte, kao i o prijevozu i prometu prirodnog i tekućeg plina te odvozu nafte iz izvora u istočnoj Slavoniji na preradu u rafineriju Pančevo u Srbiji.

Od prirodnih resursa, za krajinsko gospodarsko važnu ulogu imale su i šume. Zakonom o šumama od 25. kolovoza 1992. osnovano je Javno poduzeće „Krajina šume“ koje je upravljalo i gospodarilo nad šumama na okupiranom području, a bilo je pod izravnom upravom krajinske Vlade. ${ }^{56}$ Iako je poduzeće obuhvaćalo 35 šumarija, zbog nedostatka kadrova, opreme i sredstava, nikad nije zaživjelo u planiranom obliku. Gradivo fonda „Krajina šume“ fragmentarno je sačuvano i pruža malo podataka o djelovanju javnog poduzeća, no kao dopunski izvori vrijedni su fondovi Ministarstva poljoprivrede i Vlade RSK. Tako se u gradivu Vlade RSK nalazi podatak da su „Krajina šume“ 1994. predstavile svoj projekt „Drvo“, koji je predviđao „proizvodnju drvenih trupaca“ i njihov izvoz na talijansko tržište u kooperaciji sa srodnim srbijanskim tvrtkama (,Srbija šume“), no nije poznato je li on doista i realiziran u praksi. ${ }^{57}$ Okupirani dio Hrvatske nije raspolagao značajnim industrijskim kapacitetima, pa se gospodarstvo svelo na poljoprivredu i na eksploataciju prirodnih resursa (šuma i nafte), te su izvori nafte $\mathrm{i}$ šumska bogatstva bili meta kriminalnih radnji, o čemu je izvještavao i srbijanski tisak.

\section{Jugoslavenska narodna armija}

U arhivskom gradivu Centra fragmentarno je pohranjeno i gradivo JNA. Radi se o fondovima i zbirci: Zbirka arhivskog gradiva JNA, Vojnopomorske oblasti - Ratne mornarice Jugoslavenske narodne armije, 5. korpus Ratnoga vazduhoplovstva i protuvazdušne odbrane (RV i PVO), 9. korpus JNA, 32. korpus JNA, 10. korpus JNA, s podfondovima: 1. operativne grupe, 7. opera-

\footnotetext{
${ }^{54}$ Zakon o osnivanju javnog preduzeća za istraživanje, proizvodnju, preradu i promet nafte i prirodnog gasa, Službeni glasnik Republike Srpske Krajine, 11/1992.

${ }^{55}$ Isto.

${ }^{56}$ Zakon o šumama, Službeni glasnik Republike Srpske Krajine, 14/1992.

${ }^{57}$ HR-HMDCDR-4. Vlada „Republike Srpske Krajine“, Zapisnik 80. sjednice Vlade RSK, Knin, 6. 4. 1994., kut. 11.
} 
tivne grupe, 3. operativne grupe i 8. operativne grupe. Gradivo fonda se sastoji od serija i pripadajućih podserija nastalih radom formacija korpusa OS SFRJ.

Tijekom svog postojanja 1941-1992., JNA se sastojala od tri vida/grane: Kopnene vojske, Ratne mornarice (bojnog pomorstva) i Ratnog zrakoplovstva i protuzračne obrane, te je nekoliko puta mijenjala svoj ustroj. Od kraja 1988. JNA je bila organizirana u sustav korpusa Kopnene vojske, korpusa Ratnoga vazduhoplovstva i protuvazdušne odbrane (RV i PVO), vojnopomorskih sektora (VPS) i niz taktičkih sastava koji su bili podređeni komandama vojnih oblasti, odnosno Komandi Vojnopomorske oblasti (VPO) i Komandi RV i PVO, koje su bile strategijske skupine. Te su komande formalno bile komande Oružanih snaga SFRJ, no stvarno su bile u sustavu JNA. Vojne oblasti u miru, odnosno vojišta u ratu, podrazumijevali su i nadležnost nad postrojbama TO-a u njihovoj zoni djelovanja. Jedan od ciljeva reorganizacije JNA 1988. bilo je podređivanje TO-a komandi JNA, što je vojni vrh uspio nakon višegodišnjega lobiranja kod partijskih struktura, koje je uvjerio da promjene ne dovode $u$ pitanje prava republika i pokrajina u poslovima obrane. Premda protuzakonit, prijedlog je prihvaćen, pa je Predsjedništvo SFRJ u slučaju rata podredilo republičke i pokrajinske štabove TO-a komandama vojišta, a postrojbe TO-a komandama korpusa. ${ }^{58}$

Preustroj JNA stvorio je četiri vojne oblasti: Vojnopomorsku oblast sa sjedištem u Splitu - čija je zona odgovornosti bila: dio Istre, Primorje, Dalmacija i otoci, te crnogorsko primorje; 5 . VO sa sjedištem u Zagrebu, sa zonom odgovornosti na području Slovenije, sjeverozapadne i zapadne Hrvatske bez Istre, Banovine, Korduna i Like, a osim prištabnih postrojbi bila je sastavljena od: Riječkog (13.), Ljubljanskog (14.), Mariborskog (31.), Varaždinskog (32.) korpusa, Komande obrane grada Zagreba i 6. proleterske pješačke divizije; 1. VO sa sjedištem u Beogradu, čija se zona odgovornosti protezala na ostatak Hrvatske (istočno od crte Virovitica-Karlovac-Karlobag), BiH, Vojvodinu i dio Srbije, a bila je sastavljena (osim prištabnih postrojbi) od: Sarajevskog (4.), Banjalučkog (5.), Novosadskog (12.), Tuzlanskog (17.), Kragujevačkog (24.) i Užičkog korpusa (37.). U svom je sastavu još imala: Komandu obrane grada Beograda, Riječnu ratnu flotilu, 1. proletersku gardijsku mehaniziranu diviziju, 4. motoriziranu i 22. pješačku diviziju; 3. VO sa sjedištem u Skoplju, sa zonom odgovornosti koja je išla na ostatak Srbije, Crnu Goru, Kosovo i Makedoniju, sastav kojeg su činile: prištabne postrojbe, Titogradski (2.), Niški (21.), Bitolski (41.), Kumanovski (42.) i Prištinski (52.) korpus i 37. motorizirana divizija. ${ }^{59}$

${ }^{58}$ Davor Marijan, Slom Titove armije: Jugoslavenska narodna armija i raspad Jugoslavije 1987. - 1992. (Zagreb: Golden marketing - Tehnička knjiga; Hrvatski institut za povijest, 2008), 110-111.

${ }^{59}$ Isto. 
Nakon naredbe o razoružanju TO, 15. svibnja 1990, načelnik Generalštaba oružanih snaga potpisao je naredbu za preustroj i prekvalifikaciju snaga u Hrvatskoj i BiH. Tom naredbom ukinuta je Komanda obrane grada Zagreba, a umjesto nje osnovan je Zagrebački (10.) korpus. Korpus je osnovan od snaga na području Zagreba koje su do tada bile u sastavu Varaždinskog i Riječkog korpusa, Komande obrane grada Zagreba, 6. proleterske pješačke divizije iz Karlovca i postrojbi izravno podređenih Komandi 5. vojne oblasti. U ljeto 1990. preraspodjelom snaga na širem području Zagreba osnovan je 10. korpus. U prvoj polovici 1991. snage 5. VO su djelovanjem po načelu izvanrednih prilika onemogućavale djelovanje hrvatske policije protiv pobunjenih Srba. ${ }^{60}$

Zadatak 10. korpusa odnosio se na pacificiranje šireg područja Zagreba. Od travnja 1991. manje snage 10. korpusa angažirane su na širem području Plitvica. U svibnju 1991. godine 10. korpus ojačan je oklopnim bataljunom 51. mehanizirane brigade iz Pančeva. Od kraja lipnja djelovao je na Banovini. Prema ustroju, uz Komandu s prištabnim postrojbama, u sastavu 10. korpusa nalazile su se: 4. oklopna brigada (okbr), 140. mehanizirana brigada (mbr), 257. motorizirana brigada (mtbr), 622. mtbr, 6. mješoviti artiljerijski puk (map), 6. mješoviti protuoklopni artiljerijski puk (mpoap), 313. laki artiljerijski puk (lap) PZO, 258. inženjerijski puk, 123. pontonirski bataljun, 17. pontonirska četa, 74. pontonirska četa, 31 . mbr i 671. pontonirski bataljun. ${ }^{61}$

Temeljem zapovijedi komandanta 5. VO od 10. studenog 1991. osnovana je Komanda 3. OG, koja je, umjesto IKM Komande 13. korpusa JNA, preuzela zapovijedanje nad snagama JNA i TO pobunjenih Srba na području Like i južnog Korduna (na području Plitvice - Slunj - Ogulin - Otočac - Gospić - Sveti Rok - Udbina). Treća OG postojala je od sredine studenog 1991. do početka 1992. godine. Od osnutka do 21. prosinca 1991. nadređena joj je bila Komanda 5. VO, a potom do ukinuća sredinom siječnja 1992. Komanda 10. korpusa JNA. Komanda 3. OG nalazila se na Plitvičkim jezerima. U nadležnosti 3. OG bila je cjelokupna Lika, osim područja Gračaca, koji je bio u zoni odgovornosti 9. (Kninskog) korpusa JNA.

Po osnutku 2. VO, 10. korpus promijenio je organizacijsku strukturu. $\mathrm{Na}$ operativnoj razini ugašene su 1 . OG i 3 . OG, umjesto kojih su ustrojene tri nove operativne grupe -6 . OG za područje Like, 7 . OG za područje Banovine i 8. OG za područje Korduna. U siječnju 1992. Deseti korpus JNA sastojao se od Komande s prištabnim jedinicama, 6. OG, 7. OG, 8. OG i 580. mabr.

Sedma OG osnovana je u siječnju 1992. radi koordinacije snaga JNA i pobunjenih Srba na Banovini. Nadređena joj je bila Komanda 10. korpusa JNA i

\footnotetext{
${ }^{60}$ Zapovjedni vrh JNA: siječanj 1990. - svibanj 1992., ur. Ante Nazor i Ivan Brigović (Zagreb: Hrvatski memorijalno-dokumentacijski centar Domovinskog rata, 2010), 169-199.

${ }^{61}$ Isto.
} 
postojala je do svibnja 1992. godine. Komanda 7. OG nalazila se na Zrinskoj gori (Šamarica), a zadaća joj je bila spriječiti eventualne napade hrvatskih snaga i uspostaviti strukturu TO RSK na okupiranom području Banovine.

Osma OG osnovana je u siječnju 1992. radi koordinacije snaga JNA i pobunjenih Srba na Kordunu. Nadređena joj je bila Komanda 10. korpusa JNA i postojala je do travnja 1992. godine. Komanda 8. OG bila je na Petrovcu (Petrova gora), a zadaća joj je bila spriječiti eventualne napade hrvatskih snaga i uspostaviti strukturu TO RSK na okupiranom području Korduna ${ }^{62}$

Deveti korpus JNA osnovan je 1988. od 9. motorizirane divizije JNA i pokrivao je područje sjeverne i srednje Dalmacije. Sastav korpusa bio je sljedeći: Komanda s prištapskim postrojbama, 180. motorizirana brigada sa sjedištem u Benkovcu, 221. motorizirana brigada sa sjedištem u Kninu, 316. motorizirana brigada sa sjedištem u Sinju, 9. mješoviti artiljerijski puk i 557. mješoviti protuoklopni artiljerijski puk, 9. inžinjerijski bataljun, 70. bataljun veze, 98. sanitetski bataljun, 9. automobilski bataljun i 9. četa ABHO. Na kraju 1991., 9. korpus ušao je u sastav 2. vojne oblasti sa sjedištem u Sarajevu. ${ }^{63}$

Tridesetdrugi korpus osnovan je 1987. godine od 32. mehanizirane divizije JNA. Sjedište korpusa bilo je u Varaždinu, prema organizacijskom ustroju pokrivao je područje zapadne Hrvatske: Međimurja, Hrvatskog zagorja, Bilogore i manjeg dijela zapadne Slavonije, Moslavinu i bjelovarsko-križevačku regiju. Sastav 32. korpusa bio je sljedeći: početkom 1990. godine 32. korpus sastojao se od: Komande s PJ, 31. mehanizirane brigade, 32. mehanizirane brigade, 265. mehanizirane brigade, 140 . motorizirane brigade, 73 . motorizirane brigade, 28. partizanske divizije, 33. partizanske divizije, 32. mješovitog artiljerijskog puka, 411. mješovitog protuoklopnog artiljerijskog puka, 32. inžinjerijskog puka i 306. lakog artiljerijskog puka PVO. U ljeto 1990. godine 32. korpus predao je 31. mehaniziranu brigadu novoosnovanom 10. korpusu. Korpus je djelovao u sklopu 5. vojne oblasti, odnosno sjeverozapadnog vojišta JNA. Za vrijeme pobune Srba u zapadnoj Slavoniji i prilikom napada na policijsku postaju u Pakracu postrojbe JNA iz Bjelovara, Virovitice i Zagreba bile su zaštita pobunjenim Srbima, a Zapovjedništvo 32. korpusa postavilo je zapovjedno mjesto u gradu. Tijekom proljeća 1991. strukture 32. korpusa sudjelovale su u formiranju oružanih postrojbi pobunjenih zapadnoslavonskih Srba, kao što su izvršile i njihovo naoružavanje. ${ }^{64}$ Nakon toga omogućeno je pobunjenim Srbima da okupiraju Okučane i drže takvo stanje do vojno-re-

${ }^{62}$ Zapovjedni vrh JNA: siječanj 1990. - svibanj 1992., 191.

${ }^{63}$ Republika Hrvatska i Domovinski rat 1990.-1995.: Dokumenti institucija pobunjenih Srba u Republici Hrvatskoj (1990.-1991.). Knjiga 19., ur. Ivan Brigović, Ivan Radoš (Zagreb: Hrvatski memorijalno-dokumentacijski centar Domovinskog rata, 2007).

${ }^{64}$ Zapovjedni vrh JNA: siječanj 1990. - svibanj 1992., 192. 
darstvene operacije „Bljesak“ $1995 .{ }^{65} \mathrm{U}$ napadnoj operaciji JNA 32. korpus trebao je braniti uporišta u zoni odgovornosti i spojiti se sa snagama 1. VO. Do kraja rujna 1991. gotovo cijeli 32. korpus je zarobljen. Zarobljavanje je preživio 306. laki artiljerijski puk PVO u Borongaju i dio 33. partizanske divizije iz Dugog Sela. ${ }^{66}$

Paralelno s pripremama za prihvat mirovnih snaga UN-a, Armija se počela pripremati za povlačenje s okupiranih područja Hrvatske. Sredinom veljače 1992. Generalštab OS SFRJ zapovjedio je plansko izvlačenje postrojbi JNA iz zaštićenih područja RH i njihov smještaj u nove garnizone na području Srbije i BiH.

U prvim danima siječnja 1992. JNA je prešla na novu organizaciju, koju su činile četiri vojne oblasti, Ratna mornarica i RZ i PZO. Uslijed toga, korpus je podređen 2. VO, nastaloj preimenovanjem iz 5. VO 30. prosinca 1991. na temelju odluke krnjeg Predsjedništva SFRJ. Zona odgovornosti 2. VO bila je Bosna bez Hercegovine i privremeno okupirana područja Hrvatske, s izuzetkom istočne Slavonije, zapadnog Srijema i Baranje. ${ }^{67}$

Arhivsko gradivo fondova JNA sadrži: zahtjeve, procjene, zapovijedi, prijedloge, obavještajne informacije, analize, ratne planove, zaključke, upozorenja, instrukcije, odobrenja, borbena i operativna izvješća komande korpusa i njemu podređenih postrojbi, personalne spise (molbe za prijem u radni odnos ili za otpuštanje iz JNA, službene ocjene, rješenja o imenovanjima ili o postavljanjima na dužnost, medicinsku dokumentaciju pripadnika, potvrde, preglede stanja, popise i evidencije pripadnika), mobilizacijske spise, izvješća o izvanrednim događajima te počinjenim kaznenim i prekršajnim djelima, ratne planove, sheme, izvješća s prikupljenim saznanjima s terena i saznanja o aktivnostima HV-a, pripreme i izvođenje napadnih bojnih djelovanja, provedbu mobilizacije, planiranje i organiziranje obrane zone odgovornosti (z/o) VPO - RM te planiranje i provedbu izvlačenja komandi, jedinica i ustanova VPO s teritorija Hrvatske na nove lokacije u Bosni i Hercegovini i Crnoj Gori.

\section{Vojska Republike Srpske}

JNA se transformirala u tri srpske vojske: Vojsku Jugoslavije na teritoriju Srbije i Crne Gore, Vojsku Republike Srpske na teritoriju BiH te u Teritorijalnu obranu Republike Srpske Krajine, koja je krajem 1992. godine preimenovana u Srpsku vojsku Krajine. Kao što je i navedeno u ranijem dijelu teksta, u Centru je fragmentarno sačuvano gradivo JNA, koja je svojim transforma-

\footnotetext{
${ }^{65}$ Isto.

${ }^{66}$ Isto.

${ }^{67}$ Zapovjedni vrh JNA: siječanj 1990. - svibanj 1992., 188.
} 
cijama dijelom postala i VRS. Srpska vojska u BiH, prvotno Vojska Srpske Republike Bosne i Hercegovine, a potom Vojska Republike Srpske (VRS), nastala je kao spoj JNA u BiH i Teritorijalne obrane na područjima sa srpskom većinom. Komponenta Jugoslavenske narodne armije, 2. vojna oblast i 13. korpus u Hercegovini, Srbima su donijeli naoružanje i opremu. Dio TO BiH u srpskim područjima proglašen je 16. travnja 1992. oružanom snagom Srpske Republike BiH. ${ }^{68}$

Istodobno je Jugoslavenska narodna armija u prvim mjesecima 1992. godine razradila planove za otvaranje sukoba unutar BIH. U proljeće je 2. vojna oblast JNA ubrzano naoružavala Srbe. U travnju je u Beogradu dogovorena njezina transformacija u Vojsku Srpske Republike Bosne i Hercegovine, dok su u drugoj polovici svibnja 1992. korpusi JNA preimenovani u korpuse VRS. Preimenovanje korpusa JNA počelo je po zapovijedi Komande 2. vojne oblasti od 14. svibnja 1992. godine. Banjalučki korpus postao je 1. krajiški, Bihaćki i dio Kninskoga korpusa postali su 2. krajiški, Sarajevski je postao Sarajevsko-romanijski, Tuzlanski je postao Istočnobosanski, a Bilećki je postao Hercegovački korpus. U studenome 1992. osnovan je Drinski korpus. S iznimkom 2. krajiškog korpusa, ostali su nastavili funkcionirati s već formiranim postrojbama, kojima su se imena davala po područjima na kojima su osnovane. Vrhovni komandant VRS bio je predsjednik Republike Srpske Radovan Karadžić. Srpska vojska u BiH organizirana je u korpusnu strukturu po naslijeđu JNA, a Glavni je štab nastao preimenovanjem Komande 2. vojne oblasti. Komandant Štaba bio je general Ratko Mladić. ${ }^{69}$

U Centru se nalazi gradivo 1. krajiškog korpusa koji je svoje sjedište imao u Banja Luci, a bio je najveći korpus Vojske Republike Srpske, s operativnom zonom na području Bosanske krajine i koridora u Posavini. Infrastrukturu i većinu borbenih sredstava naslijedio je od 5. korpusa JNA. Dokumentacija korpusa, iako fragmentarno sačuvana, sadrži prikaz vojnog djelovanja korpusa u zauzimanju dijela Bosanske Posavine. U razdoblju od svibnja do prosinca 1992. godine, popunjenost 1. krajiškog korpusa značajno je uvećana mobilizacijom i uključivanjem bivših jedinica teritorijalne odbrane (koje su preimenovane u lake brigade) u sastav korpusa. Nove su postrojbe uglavnom bile lake pješačke brigade, koje su se načelno formirale na razini općina.

Drugi krajiški korpus nalazio se u zapadnoj i jugozapadnoj Bosni i imao je sjedište u Drvaru. Zona djelovanja Istočnobosanskoga korpusa bila je u sjeveroistočnoj Bosni, a Komanda u Ugljeviku i Bijeljini. Te su borbe dovele do prve bihaćke krize, koja je ujedno bila i početak trećega dijela rata, razdoblja napadnih operacija hrvatskih snaga i ARBiH koje su trajale do kraja 1995.

\footnotetext{
${ }_{68}^{6}$ Marijan, Slom Titove armije, 375-380.

${ }^{69}$ Isto.
} 
godine. U studenome 1994. Hrvatsko vijeće obrane, u koordinaciji s ARBiH, zauzelo je Kupres. Hrvatske snage (HV i HVO) pod zapovijedanjem generala Ante Gotovine, s ojačanjima su od kraja studenoga 1994. do lipnja 1995. na Livanjskom polju i planinskom masivu Dinare potukle 2. krajiški korpus Vojske Republike Srpske, zauzele Glamoč i Bosansko Grahovo te ostvarile povoljne uvjete za oslobađanje Knina. Gradivo 2. krajiškog korpusa odnosi se na napadne operacije hrvatskih snaga i ARBiH koje su trajale do kraja 1995. godine.

\section{Zaključak}

Arhivsko gradivo paradržavnih tijela vlasti i vojske na okupiranom području Hrvatske 1990.-1995. pohranjeno u HMDCDR-u sadrži zapise civilnih i vojnih ustanova osnovanih od strane pobunjenih Srba. Kao stvaratelji gradiva civilne provenijencije mogu se identificirati paradržavna tijela političke vlasti, političkih stranaka i ostalih civilnih ustanova, a kao stvaratelji gradiva vojne provenijencije JNA/VJ i vojne ustanove i postrojbe pobunjenih Srba u $\mathrm{RH}$, a postupak sređivanja pokušava pratiti njihovu organizacijsku strukturu.

Ipak, neposrednim uvidom u gradivo, može se zaključiti da je gradivo vojne provenijencije sveobuhvatnije te da je stvarano i vođeno sustavnije nego gradivo civilne provenijencije. Mogući razlog za to je korištenje razrađenijeg sustava vođenja i odlaganja spisa preuzetog od JNA, te činjenica da su oficiri i podoficiri SVK većinom dolazili upravo iz JNA. Kao temeljni izvor podataka služi i izvorno arhivsko gradivo JNA te se može zaključiti da je arhivsko gradivo srpske provenijencije izvorno gradivo koje svakako predstavlja primarni historiografski izvor pri proučavanju Domovinskog rata.

Iako arhivski fondovi i zbirke nisu ni cjeloviti niti su fizički pohranjeni u jednoj ustanovi, arhivistička obrada i izrada obavijesnih pomagala omogućit će njihovo lakše pretraživanje i korištenje, a postavljena struktura olakšat će postupak daljnjeg oblikovanja fondova, kao preduvjet sustavnog arhivističkog sređivanja i njihove dostupnosti. 


\section{RAZREDBA ARHIVSKIH FONDOVA I ZBIRKI}

\section{A. UPRAVA}

HR-HMDCDR-3. Skupština „Republike Srpske Krajine“ (1991.-1995.), 10 kut.

HR-HMDCDR-4. Vlada „Republike Srpske Krajine“ (1991.-1995.), 45 kut.

HR-HMDCDR-04/4-1. Komisije za razmjenu zarobljenika Vlade „RSK“, 1 kut.

HR-HMDCDR-04/4-2. Komisije za humanitarna pitanja Vlade „RSK“, 1994., 1 kut.

HR-HMDCDR-04/4-3. Komisije za popis i procjenu ratne štete „RSK“, 1994.-1995., 1 kut.

HR-HMDCDR-04/4-4. Državni komitet „RSK“ za suradnju s UNPROFOR-om, 1992.-1993., 1 kut.

HR-HMDCDR-04-01/1. Ministarstvo inostranih poslova „RSK“, 1991.-1995., 1 kut. HR-HMDCDR-04-01/2. Ministarstvo finansija „RSK“, 1991.-1995., 1 kut.

HR-HMDCDR-04-01/3. Ministarstvo pravosuđa i uprave „RSK“, 1991.-1995., 5 kut.

HR-HMDCDR-04-01/4. Ministarstvo za ekonomske odnose, privredni razvoj i industriju „RSK“, 1991.-1995., 1 kut.

HR-HMDCDR-04-01/5. Ministarstvo poljoprivrede, šumarstva i vodoprivrede „RSK“, 1991.-1995., 1 kut.

HR-HMDCDR-04-01/6. Ministarstvo energetike i rudarstva „RSK“, 1991.-1995., 1 kut.

HR-HMDCDR-04-01/7. Ministarstvo za saobraćaj i veze „RSK“, 1991.-1995., 1 kut. HR-HMDCDR-04-01/8. Ministarstvo za urbanizam, stambeno-komunalne poslove i građevinarstvo „RSK“, 1991.-1995., 1 kut.

HR-HMDCDR-04-01/9. Ministarstvo prosvjete, kulture i fizičke kulture

HR-HMDCDR-04-01/10. Ministarstvo prosvjete „RSK“, 1991.-1995., 1 kut.

HR-HMDCDR-04-01/11. Ministarstvo kulture i vjera „RSK“, 1991.-1995., 1 kut.

HR-HMDCDR-04-01/12. Ministarstvo fizičke kulture i sporta „RSK“, 1991.-1995., 1 kut.

HR-HMDCDR-04-01/13. Ministarstvo zdravstva i zdravstvenog osiguranja „RSK“, 1991.-1995., 1 kut.

HR-HMDCDR-04-01/14. Ministarstvo informisanja „RSK“, 1991.-1995., 3 kut.

HR-HMDCDR-04-01/15. Ministarstvo za rad, boračka i socijalna pitanja „RSK“, 1991.-1995., 1 kut.

HR-HMDCDR-04-01/16. Ministarstvo trgovine i turizma „RSK“, 1991.-1995., 1 kut. HR-HMDCDR-5. Ministarstvo odbrane „RSK“, 1991.-1995., 24 kut.

HR-HMDCDR-19. Ministarstvo odbrane „RSK“ - uprava zapadna Slavonija, 1991.1995., 16 arhivskih kut., 15 drvenih kut., 2 knjige (dalje knj.) 4,30 d/m

HR-HMDCDR-28. Ministarstvo odbrane „RSK“ - uprava sjeverna Dalmacija, 1991.1995., 11 kut. 
HR-HMDCDR-35. Ministarstvo odbrane "RSK" - uprava istočna Slavonija, Baranja i zapadni Srem, 1991.-1995., 2 kut.

HR-HMDCDR-73. Ministarstvo odbrane , RSK“ - uprava Lika, 1991.-1995., 19 kut. HR-HMDCDR-74. Ministarstvo odbrane „, RSK“ - uprava Banija, 1991.-1995., 4 kut. HR-HMDCDR-75. Ministarstvo odbrane „, RSK“ - uprava Kordun, 1991.-1995., 2 kut.

\section{HR-HMDCDR-20. Ministarstvo unutrašnjih poslova „RSK“, 1991.-1995., 4} knj. i 38 kut.

HR-HMDCDR-20/1. Posebne jedinice milicije (PJM) Banija, 1991.-1995., 4 kut. HR-HMDCDR-20/2. Posebne jedinice milicije (PJM) Benkovac, 1991.-1995., 1 kut. HR-HMDCDR-20/3. Posebne jedinice milicije (PJM) Bunić, 1991.-1995., 1 kut. HR-HMDCDR-20/4. Posebne jedinice milicije (PJM) Gračac, 1991.-1995., 2 kut. HR-HMDCDR-20/5. Posebne jedinice milicije (PJM) Korenica, 1991.-1995., 3kut. HR-HMDCDR-20/6. Posebne jedinica milicije (PJM) Plaški, 1991.-1995., 1 kut. HR-HMDCDR-20/7. Posebne jedinica milicije (PJM) Vojnić, 1991.-1995., 5 kut. HR-HMDCDR-20/8. Posebne jedinica milicije (PJM) Vrginmost, 1991.-1995., 1 kut. HR-HMDCDR-20/9. Posebne jedinice milicije (PJM) Vrhovine, 1991.-1995., 1 kut. HR-HMDCDR-20/10. Posebne jedinice milicije (PJM) zapadna Slavonija, 1991.1995., 1 kut.

HR-HMDCDR-41. Sekretarijat za unutrašnje poslove Beli Manastir, 1991.-1997., 6 kut.

HR-HMDCDR-76. Sekretarijat za unutrašnje poslove Glina, 1991.-1995., 21 kut. HR-HMDCDR-76/1. Stanica javne bezbjednosti (SJB) Dvor na Uni, 1992.-1995., 2 kut.

HR-HMDCDR-76/2. Stanica javne bezbjednosti (SJB) Glina, 1992.-1995., 48 kut. HR-HMDCDR-76/3. Stanica javne bezbjednosti (SJB) Kostajnica, 1992.-1995., 2 kut.

HR- HMDCDR-76/3/1. Stanica milicije Dubica, 1991.-1992.

HR-HMDCDR-76/4. Stanica javne bezbjednosti (SJB) Petrinja, 1992.-1995., 3 kut. HR-HMDCDR-23. Sekretarijat za unutrašnje poslove Knin, 1991.-1995., 49 kut. HR-HMDCDR-31. Sekretarijat za unutrašnje poslove Korenica, 1991.-1995., 4 kut. HR-HMDCDR-10. Sekretarijat za unutrašnje poslove Okučani, 1991.-1995., 115 kut. HR-HMDCDR-77. Sekretarijat za unutarnje poslove Vojnić, 1991.-1995., 30 kut. HR-HMDCDR-77/1. Stanica javne bezbjednosti (SJB) Slunj, 1992.-1995., 6 kut. HR-HMDCDR-37. Sekretarijat za unutarnje poslove Vukovar, 1991.-1995, 3 knj., 13 kut.

HR-HMDCDR-14. Skupštine općina Zajednice općina Sjeverna Dalmacija i Lika 1990.- 1991. / Srpska autonomna oblast Krajina - SAO Krajina / 4 kut. HR-HMDCDR-14/1. Skupština općine Benkovac „SAO Krajina“, 1991.-1995., 1 kut. 
HR-HMDCDR-14/2. Skupština općina Donji Lapac „SAO Krajina“, 1991.-1995., 1 kut.

HR-HMDCDR-14/3. Skupština općine Drniš „SAO Krajina“, 1991.-1995., 9 kut.

HR-HMDCDR-14/4. Skupština općine Dvor na Uni „SAO Krajina“, 1991.-1995., 3 kut.

HR-HMDCDR-14/5. Skupština općine Glina „SAO Krajina“, 1991.-1995., 18 kut. HR-HMDCDR-14/6. Skupština općine Gračac „SAO Krajina“, 1991.-1995., 10 kut. HR-HMDCDR-14/7. Skupština općine Knin „SAO Krajina“, 1991.-1995., 7 kut.

HR-HMDCDR-14/8. Skupština općine Korenica „SAO Krajina“, 1991.-1995., 4 kut. HR-HMDCDR-14/9. Skupština općine Kostajnica „SAO Krajina“, 1991.-1995., 1 kut.

HR-HMDCDR-14/10. Skupština općine Krnjak „SAO Krajina“, 1991.-1995., 2 kut. HR-HMDCDR-14/11. Skupština općine Obrovac „SAO Krajina“, 1991.-1995., 1 kut. HR-HMDCDR-14/12. Skupština općine Petrinja „SAO Krajina“, 1991.-1995., 13 kut. HR-HMDCDR-14/13. Skupština općine Plaški „SAO Krajina“, 1991.-1995., 3 kut. HR-HMDCDR-14/14. Skupština općine Sisak/Caprag „SAO Krajina“, 1991.-1995., 3 kut.

HR-HMDCDR-14/15. Skupština općine Slunj „SAO Krajina“, 1991.-1995., 6 kut. HR-HMDCDR-14/16. Skupština općine Teslingrad „SAO Krajina“, 1991.-1995., 1 kut.

HR-HMDCDR-14/17. Skupština općine Vojnić „SAO Krajina“, 1991.-1995., 1 kut. HR-HMDCDR-14/18. Skupština općine Vrginmost „SAO Krajina“, 1991.-1995., 1 kut.

HR-HMDCDR-14/19. Skupština općine Vrhovine „SAO Krajina“, 1991.-1995., 6 kut.

HR-HMDCDR-15. Srpska oblast Zapadne Slavonije - Skupština općine Pakrac 1991.- 1995., 26 kut.

HR-HMDCDR-27. Vrhovni savet obrane „RSK“, 1993.-1995., 4 kut.

\section{B. PRAVOSUĐE}

HR-HMDCDR-29. Vrhovni sud „RSK“, 1992.-1995., 17 registratora

HR-HMDCDR-6. Okružni sud Knin, 1992.-1995., 57 kut. i 14 knj.

HR-HMDCDR-36/1. Općinski sud Knin, 1991.-1995., 1 kut.

HR-HMDCDR-36/2. Općinski sud Gračac, 1990., 1 kut.

HR-HMDCDR-36/3. Općinski sud Korenica, 1992., 2 kut.

HR-HMDCDR-36/4. Općinski sud Benkovac, 1991.-1995., 2 kut.

\section{HR-HMDCDR-78. Okružni sud u Glini 1991.-1995., 5 kut.}

HR-HMDCDR-78/1. Općinski sud Glina, 1991.-1995., 2 kut.

HR-HMDCDR-78/1. Općinski sud Okučani, 1991.-1995., 1 kut. 
HR-HMDCDR-78/1. Općinski sud Vojnić, 1991.-1995., 1 kut.

HR-HMDCDR-65. Okružno javno tužilaštvo Knin, 1991.-1995., 43 kut.

HRHMDCDR-79. Okružno javno tužilaštvo Glina, 1991./1995., 2 kut.

HR-HMDCDR-80. Republički sud „RSK“ za prekršaje u Kninu, 1991.-1995., 3 kut.

HR-HMDCDR-81. Kazneno-popravni dom Glina, 1991.-1995., 2 kut.

HR-HMDCDR-82. Okružni zatvor Glina, 1992.-1995., 6 kut.

HR-HMDCDR-30. Okružni zatvor Knin, 1991.-1995., 13 kut.

\section{VOJSKA REPUBLIKE SRPSKE KRAJINE}

HR-HMDCDR-6. Glavni štab Vojske Republike Srpske Krajine (Glavni štab TO SAO Krajine; Glavni štab TO Republike Srpske Krajine) - VP 9000

\section{ZONSKI ŠTABOVI TERITORIJALNE OBRANE VRSK}

HR-HMDCDR-177. Zonski štab teritorijalne obrane Sjeverna Dalmacija - VP T-7901 (I operativna zona TO)

HR-HMDCDR-177/1. Općinski štab TO Knin

HR-HMDCDR-177/2. Općinski štab TO Benkovac

HR-HMDCDR-177/3. Općinski štab TO Obrovac

HR-HMDCDR-178. 1. brigada TO (Knin) VP T-7902

HR-HMDCDR-179. 1. brigada TO (Knin) VP T-7903

HR-HMDCDR-180. 3. brigada TO (Benkovac) VP T-7904

HR-HMDCDR-181. 4. brigada TO (Obrovac) VP T-7905

HR-HMDCDR-149. Zonski štab teritorijalne obrane Lika - VP T-7906 (II operativna zona)

HR-HMDCDR-196/1. Općinski štab TO Korenica

HR-HMDCDR-196/2. Općinski štab TO Gračac

HR-HMDCDR-196/3. Općinski štab TO Donji Lapac

HR-HMDCDR-196/4. Općinski štab TO Plaški

HR-HMDCDR-124. 6. divizija JNA Korenica

HR-HMDCDR-127. 1. motorizirana brigada TO (Gračac)

HR-HMDCDR-126. 1. brigada TO (Gračac)

HR-HMDCDR-59. 2. lička brigada TO Vrhovine VP T-7903

HR-HMDCDR-181. 4. brigada TO VP T-7905

HR-HMDCDR-146. 7. brigada TO VP 7907

HR-HMDCDR-147. 8. brigada TO VP 7908

HR-HMDCDR-120. 145. brigada TO VP 7910

HR-HMDCDR-180. 93. odred TO VP T-7984 
HR-HMDCDR-176. Zonski štab teritorijalne obrane Banija - Vojna pošta T-7916 (IV operativna zona)

HR-HMDCDR-176/1. Općinski štab TO Glina

HR-HMDCDR-176/2. Općinski štab TO Kostajnica

HR-HMDCDR-176/3. Općinski štab TO Dvor na Uni

HR-HMDCDR-176/4. Općinski štab TO Petrinja

HR-HMDCDR-176/5. Općinski štab TO Sisak

\section{HR-HMDCDR-182. Zonski štab teritorijalne obrane Kordun - Vojna pošta} T-7911 (IV operativna zona)

HR-HMDCDR-182/1. Općinski štab TO Vojnić

HR-HMDCDR-182/2. Općinski štab TO Vrginmost

HR-HMDCDR-182/3. Općinski štab TO Slunj

HR-HMDCDR-182/4. Općinski štab TO Karlovac

HR-HMDCDR-154. 3. kordunaška brigada TO

HR-HMDCDR-155. 4. kordunaška brigada TO

HR-HMDCDR-156. 5. kordunaška brigada TO

HR-HMDCDR-12. Zonski štab teritorijalne obrane zapadna Slavonija - Vojna pošta T-7916 (V operativna zona)

HR-HMDCDR-12/1. Općinski štab TO Pakrac

HR-HMDCDR-12/2. Općinski štab TO Daruvar

HR-HMDCDR-12/3. Općinski štab TO Podravska Slatina

HR-HMDCDR-12/4. Općinski štab TO Okučani

HR-HMDCDR-12/5. Općinski štab TO Grubišno Polje

HR-HMDCDR-12/6. Općinski štab TO Slavonska Požega

HR-HMDCDR-12/7. Općinski štab TO Novska

HR-HMDCDR-148. 51. odred TO (Pakrac)

HR-HMDCDR-22. 54. brigada TO (Okučani) VP 9165

HR-HMDCDR-34. 63. odred TO (Daruvar) VP 9168

HR-HMDCDR-35. 59. odred TO (Podravska Slatina) VP 9169

HR-HMDCDR-192. 98. odred TO (Rajić)

HR-HMDCDR-195. 61. haubičko-artiljerijski divizion (had Pakrac)

HR-HMDCD-193. 83. mješoviti protuoklopni artiljerijski divizijun (mpoad)

- Okučani

HR-HMDCDR-194. 45. lako artiljerijska baterija protuvazdušne obrane (lab PVO)

- Okučani

HR-HMDCDR-142. 91. pozadinska baza (Okučani) VP 9172 


\section{KORPUSI VRSK}

\section{HR-HMDCDR-8. 7. sjevernodalmatinski korpus SVK (Knin) VP 9031}

HR-HMDCDR-8/1. 1. laka brigada (Vrlika) VP

HR-HMDCDR-8/2. 2. pješadijska brigada (Kistanje) VP

HR-HMDCDR-8/3. 3. pješadijska brigada (Benkovac) VP

HR-HMDCDR-8/4. 4. laka brigada (Obrovac) VP

HR-HMDCDR-8/5. 75. motorizirana brigada (Drniš) VP

HR-HMDCDR-8/6. 92. motorizirana brigada (Benkovac) VP

\section{HR-HMDCDR-41. 15. lički korpus SVK (Korenica) VP 9065}

HR-HMDCDR-117. 9. motorizirana brigada (Gračac) VP 9068

HR-HMDCDR-118. 18. pješadijska brigada (Bunić) VP 9069

HR-HMDCDR-119. 50. pješadijska brigada (Vrhovine) VP 9071

HR-HMDCDR-120. 70. pješadijska brigada (Plaški) VP 9073

HR-HMDCDR-121. 103. laka pješadijska brigada (Donji Lapac) VP 9074

HR-HMDCDR-122. 37. pješadijski bataljun (Korenica) VP 9076

HR-HMDCDR-123. 81. pozadinska baza (Željava) VP 9081

\section{HR-HMDCDR-196. 21. kordunaški korpus SVK (Petrova gora) VP 9104}

HR-HMDCDR-128. 11. pješadijska brigada (Vojnić) VP 9106 (VP T-7912)

HR-HMDCDR-129. 13. pješadijska brigada (Slunj) VP 9107 (VP T-7913)

HR-HMDCDR-130. 19. pješadijska brigada (Gvozd) VP 9109 (VP T-7914)

HR-HMDCDR-131. 75. mješovita artiljerijska brigada (Slunj) VP 9111

HR-HMDCDR-132. 75. mješoviti artiljerijski divizijun (Blatuša) VP 9114

HR-HMDCDR-133. 85. pozadinska baza (Slunj) VP 9117 (VP T-79121)

\section{HR-HMDCDR-52. 39. banijski korpus SVK (Petrinja) VP 9136}

HR-HMDCDR-134. 24. pješadijska brigada (Glina) VP 9138

HR-HMDCDR-135. 26. pješadijska brigada (Kostajnica) VP 9139

HR-HMDCDR-136. 31. pješadijska brigada (Petrinja) VP 9142

HR-HMDCDR-137. 33. pješadijska brigada (Dvor na Uni) VP 9143

HR-HMDCDR-139. 87. pozadinska baza (Glina) VP 9146 (VP T-7926)

HR-HMDCDR-138. Odred Sisak - Caprag (Caprag) VP 9144

\section{HR-HMDCDR-44. 18. zapadnoslavonski korpus SVK}

HR-HMDCDR-140. 51. pješadijska brigada (Pakrac) VP 9164

HR-HMDCDR-22. 54. brigada VP 9165

HR-HMDCDR-21. 98. pješadijska brigada (Jasenovac) VP 6167

HR-HMDCDR-35. 59. odred (Podravska Slatina) VP 9169 
HR-HMDCDR-34. 63. odred (Daruvar) VP 9168

HR-HMDCDR-142. 91. pozadinska baza (Okučani) VP 9172

HR-HMDCDR-173. 18. MAP (Stara Gradiška) VP 9174

HR-HMDCDR-174. Taktička grupa (Jasenovac) VP 9162

HR-HMDCDR-141. Bataljun za intervencije (Okučani) VP 9171 (9168)

HR-HMDCDR-49. 11. slavonsko-baranjski korpus SVK VP 9189

HR-HMDCDR-49/1. 35. pješadijska brigada

HR-HMDCDR-49/2. 40. pješadijska brigada

HR-HMDCDR-49/3. 43. pješadijska brigada

HR-HMDCDR-49/4. 45. pješadijska brigada

HR-HMDCDR-49/5. 1. baranjska divizija

HR-HMDCDR-197. Gardijska brigada VRSK

\section{VOJSKA REPUBLIKE SRPSKE}

HR-HMDCDR, 198, 1. krajiški korpus VRS

HR-HMDCDR, 199, 2. krajiški korpus VRS

\section{JUGOSLAVENSKA NARODNA ARMIJA}

HR-HMDCDR, 201, Zbirka arhivskog gradiva JNA

HR-HMDCDR, 7, 9. korpus JNA

HR-HMDCDR, 153, 32. korpus JNA

HR-HMDCDR, 202, 10. korpus JNA

HR-HMDCDR, 202/1, 1. operativna grupa

HR-HMDCDR, 202/2, 7. operativna grupa

HR-HMDCDR, 202/3, 3. operativna grupa

HR-HMDCDR, 202/4, 8. operativna grupa

HR-HMDCDR, 203, 5. korpus RV i PVO

HR-HMDCDR, 204, Vojnopomorske oblasti - ratne mornarice JNA

\section{E. KULTURA, ZNANOST I INFORMIRANJE}

HR-HMDCDR-39. Srpski radio Okučani 1991.-1995., 5 kut.

\section{F. ZDRAVSTVO}

HR-HMDCDR-83. Opća bolnica sv. Georgije Vojnić 1993., 1 kut.

HR-HMDCDR-84. Medicinski centar Glina 1993.-1995., 1 kut.

HR-HMDCDR-87. Crveni križ Drniš 1991./1995., 5 kut. 


\section{G. GOSPODARSTVO}

HR-HMDCDR-85. Krajinske šume Vrginmost 1991./1995, 2 kut.

HR-HMDCDR-86. Naftna industrija Krajine 1992.-1995., 14 kut.

\section{H. POLITIČKE STRANKE, DRUŠTVENO-POLITIČKE ORGANIZACIJE I SINDIKATI}

HR-HMDCDR-29. Zbirka političkih stranaka i pokreta u „RSK“ 1990.-1995., 10 kut.

\section{VJERSKE USTANOVE}

HR-HMDCDR-34. Srpska pravoslavna crkva 1991./1995., 3 kut.

\section{IZVORI I LITERATURA:}

\section{Arhivsko gradivo:}

Hrvatski memorijalno-dokumentacijski centar Domovinskog rata:

HR-HMDCDR-2. Paradržavne i paravojne postrojbe na okupiranom području RH 1990.-1995.

HR-HMDCDR-4. Vlada "Republike Srpske Krajine"

HR-HMDCDR-6. Glavni štab „Srpske vojske Krajine“

HR-HMDCDR-26. Štab teritorijalne obrane Zapadne Slavonije

HR-HMDCDR- 27. Vrhovni savjet obrane „Republike Srpske Krajine“

HR-HMDCDR, 7. 9. korpus JNA

HR-HMDCDR, 153. 32. korpus JNA

HR-HMDCDR, 202. 10. korpus JNA

Državni arhiv u Sisku - Sabirni centar Petrinja:

HR-DASK-SACPE-610. Skupština općine Dvor.

\section{Službena glasila i tisak:}

1. Izvješće u povodu Inicijative Vlade Republike Hrvatske za davanje mišljenja o pojedinim ustavnopravnim aspektima oslobodilačkih akcija Domovinskog rata i s njima povezanim ovlastima i dužnostima oružanih snaga Republike Hrvatske. Ustavni sud RH, klasa: 004-01/02-02/12, urudžbeni broj: 5030109-02-2, 10. listopada 2002.

2. Krajina magazin (Knin), 1995.

3. Narodne novine (Zagreb), 2004. 
4. Službeni glasnik Republike Srpske Krajine (Knin), 1992.

5. Službeni glasnik Republike Srpske Krajine (Knin), 1993.

6. Službeni glasnik Republike Srpske Krajine (Knin), 1994.

7. Službeni glasnik Srpske oblasti Slavonija, Baranja i Zapadni Srem (Vukovar), 1991.

8. Službeni vjesnik općine Drniš, Knin i Šibenik(Knin), 1990.

9. Srpske novine (Knin), 1992.

\section{Literatura:}

1. Barić, Nikica. Srpska pobuna u Hrvatskoj 1990.-1995. Zagreb: Golden marketing - Tehnička knjiga, 2005.

2. Barunčić Pletikosić Julija, Križe Gračanin Željka. „Ustroj i djelovanje 18. korpusa Srpske vojske Krajine.“,U Srpska pobuna u zapadnoj Slavoniji 1990. - 1995. Slavonski Brod - Zagreb: Hrvatski institut za povijest - Podružnica za povijest Slavonije, Srijema i Baranje; Hrvatski memorijalno-dokumentacijski centar Domovinskog rata , 2012.

3. Brigović Ivan, Martinić Jerčić Natko, Radoš Ivan, ur. Republika Hrvatska i Domovinski rat 1990.-1995. : Dokumenti institucija pobunjenih Srba u Republici Hrvatskoj ( svibanj - listopad 1995.). Knjiga 17. Zagreb: Hrvatski memorijalnodokumentacijski centar Domovinskog rata, 2007.

4. Ćosić Ivica, Landeka Marko. „Štete na arhivskom gradivu u Podunavlju za vrijeme agresije na Hrvatsku od 1991. do 1998. godine." U Glasnik arhiva Slavonije i Baranje 5 (1999): str. 183-192.

5. Holjevac Tuković, Ana. „Hrvatski istok kroz djelovanje mirovnih misija Ujedinjenih naroda u Domovinskom ratu. " U Hrvatski istok u Domovinskog rataiskustva, spoznaje i posljedice : Zbornik Instituta Ivo Pilar. Knjiga 48. Zagreb: Institut društvenih znanosti Ivo Pilar, Područni centar Osijek, 2015.

6. Holjevac Tuković, Ana, Mate Rupić, „, Arhivski fondovi paradržavnih ustanova Republike Srpske Krajine pohranjeni u Hrvatskom memorijalno dokumentacijskom centru Domovinskog rata“" u: Arhivi i Domovinski rat, 49. savjetovanje hrvatskih arhivista, 26. - 28. listopada 2016. Plitvice, ur. Silvija Babić, Zagreb: Hrvatsko arhivističko društvo, 2016.

7. Jović, Borisav. Poslednji dani SFRJ: Izvodi iz dnevnika. Beograd: Politika, 1995.

8. Knežević, Domagoj. , Srpska demokratska stranka od osnivanja do konstituiranja prvoga višestranačkog Sabora." Časopis za suvremenu povijest 43, 1 (2011): str. $7-24$.

9. Kolanović Josip, Pavliček Vida, ur. Pregled arhivskih fondova i zbirki Republike Hrvatske. Sv. 1. Zagreb: Hrvatski državni arhiv, 2006.

10. Marijan, Davor. Hrvatsko ratište 1990. - 1995.: Stvaranje hrvatske države i Domovinski rat. Zagreb: Školska knjiga, 2006. 
11. Marijan, Davor. Slom Titove armije: Jugoslavenska narodna armija i raspad Jugoslavije 1987. - 1992., Zagreb: Golden marketing - Tehnička knjiga i Hrvatski institut za povijest 2008.

12. Martinić Jerčić, Natko. „HR- HMDCDR- 6. Glavni štab Srpske vojske Krajine. „S Sumarni inventar, Hrvatski memorijalno dokumentacijski centar Domovinskog rata, Zagreb: 2007.

13. Nazor, Ante; Brigović, Ivan (ur.). Zapovjedni vrh JNA: siječanj 1990. - svibanj 1992. Zagreb: Hrvatski memorijalno-dokumentacijski centar Domovinskog rata, Ministarstvo obrane Republike Hrvatske, 2010.

14. Novaković, Kosta. Srpska Krajina: usponi, padovi, uzdizanja. Beograd: Srpsko kulturno društvo Zora- Knin, 2009.

15. Radoš, Ivan. „HR- HMDCDR- 8. 7. Korpus Srpske vojske Krajine.“ Sumarni inventar, Hrvatski memorijalno dokumentacijski centar Domovinskog rata, Zagreb, 2007.

16. Republika Hrvatska - Ministarstvo informiranja: Dossier: Knin (veljača 1990./ veljača 1991.). Zagreb: Ministarstvo informiranja Republike Hrvatske, 1991.

17. Rupić, Mate, ur. Oružana pobuna Srba u Hrvatskoj i agresija oružanih snaga SFRJ i srpskih paravojnih postrojbi na Republiku Hrvatsku. Knjiga 3. Zagreb: Hrvatski memorijalno dokumentacijski centar Domovinskog rata, 2008.

18. Rupić, Mate, ur. Republika Hrvatska i Domovinski rat 1990.-1995. Dokumenti institucija pobunjenih Srba u Republici Hrvatskoj (1990.-1991.). Knjiga 2. Zagreb: Hrvatski memorijalno dokumentacijski centar Domovinskog rata, 2008.

19. Ružić, Slaven. Djelovanje „,Vlade Republike Srpske Krajine“ 1991.-1995., Zagreb: Hrvatski memorijalno dokumentacijski centar Domovinskog rata, 2017.

20. Ružić, Slaven. „HR- HMDCDR- 4. Vlada Republike srpske Krajine.“ Sumarni inventar, Hrvatski memorijalno dokumentacijski centar Domovinskog rata, Zagreb, 2007.

21. Sekulić, Milisav. Knin je pao u Beogradu. Bad Vilbel: Nidda Verlag GmbH, 2000.

22. Štefančić, Domagoj. „HR- HMDCDR- 26. Štab teritorijalne obrane Zapadne Slavonije." Sumarni inventar, Hrvatski memorijalno-dokumentacijski centar Domovinskog rata, Zagreb, 2008.

23. Valentić, Mirko. Rat protiv Hrvatske 1991. - 1995.: Velikosrpski projekti od ideje do realizacije. Zagreb: Hrvatski institut za povijest - Podružnica za povijest Slavonije, Srijema i Baranje, Hrvatski memorijalno-dokumentacijski centar Domovinskog rata, 2010.

24. Vučur, Ilija; Sekula, Janja. „Pregled arhivskoga gradiva vojne provenijencije Republike Srpske Krajine u Hrvatskome memorijalno-dokumentacijskom centru Domovinskoga rata i državnim arhivima Republike Hrvatske“. U: Arhivi $i$ Domovinski rat, 49. savjetovanje hrvatskih arhivista, ur. Silvija Babić, Zagreb: Hrvatsko arhivističko društvo, 2016. 


\section{Summary}

\section{CIVIL AND MILITARY ARCHIVAL HOLDINGS OF SERBIAN PROVENANCE STORED AT THE CROATIAN MEMORIAL- DOCUMENTATION CENTRE OF THE HOMELAND WAR}

This article provides an overview of archival holdings and collections of the civic and military institutions of the para-state of the rebel Serbs in the Republic of Croatia in the period from 1990 to 1995 , that is to say the archival records set up in the occupied territory of the Republic of Croatia as well as those of the JNA (Yugoslav People's Army). At issue are the materials that were the result of the work of the "Republic of Serbian Krajina", of its parliament, government, ministries, judicial authorities and governing bodies at the local level as well as that of the political parties and associations, the corps of the Serbian Army of Krajina and its predecessors (zone headquarters). In other words, on the basis of stored archival materials, a review of the activities of the JNA, of its transformation and role during the aggression against Croatia is provided. The contents of the archival holdings of the institutions of the "Republic of Serbian Krajina" indicate the intention of their creators and their focus on the partition of the territory of the Republic of Croatia and annexing a part to the Republic of Serbia and Yugoslavia. The materials were collected after the military-police liberating operations Bljesak and Oluja, and then transferred to the Croatian State Archive and at the end of 2005 to the Croatian Memorial-Documentation Centre of the Homeland War.

Keywords: Homeland War, archival holdings and collections of the Republic of Serbian Krajina, Yugoslav People's Army, Croatian Memorial-Documentation Centre of the Homeland War, structure of administrative and military archival holdings and collections

(Translated by Mica Orban Kljajić)

\section{Kontakt autorâ:}

dr. sc. Ana Holjevac Tuković, viši arhivist

e-mail: ana.holjevac@centardomovinskograta.hr

Mate Rupić, prof., viši arhivist

e-mail: mate.rupic@centardomovinskograta.hr

Hrvatski memorijalno-dokumentacijski centar Domovinskog rata, Marulićev trg 21, Zagreb 